\title{
EENIGE BESCHOUWINGEN OVER INHOUD, COMPOSITIE, AARD EN HERKOMST VAN HET AGASTYAPARWA.
}

DOOR

\author{
Prof. Dr. J. GONDA.
}

Wanneer wij in het kort den inhoud van het Agastyaparwa samenvatten ${ }^{1}$ ), dan geeft het werk weer een gesprek tusschen Agastya en zijn zoon Dṛ̂hhasyu. Laatstgenoemde stelt vragen, die zijn vader, meestal uitvoerig, beantwoordt. Dṛ̣hasyu begint te vragen naar de aanvang der wereld; zijn vader zet deze uiteen, leert hem, dat bij een wereld-ondergang alles ten gronde gaat, doch alleen bhațāara Sadāçiwa blijft leven; deze is het, die een nieuwe schepping voortbrengt: de vier grove elementen, het kosmische ei doet hij ontstaan, Brahmā en Wiṣnu komen in het aanzijn; Brahmā doet dan de Prajāpati’s, Brahmarși's, Manu's, Pitaras enz. in het aanzijn treden. Hier valt Dṛ̣̂hasyu zijn vader in de rede met de vraag, hoe precies de Brahmarși's zijn ontstaan. Dit wordt hem uitgelegd: ze zijn geboren uit deelen van Brahmā's lichaam: Marīci en Ruci uit de oogen, Bhrgu uit 't hart, enz. De veertien Manu's, zoo vervolgt Agastya dan, zijn geboren uit deze Brahmarși's. Hij noemt hun namen, waarop z'n zoon weer een vraag stelt: hoe lang duurde het bewind van ieder dier veertien Manu's? Agastya zegt het hem: één-en-zeventig yuga's; zoo'n periode heet Manwantara. Dan komt Dṛ̣̂hasyu al spoedig met 'n vraag, die het gesprek in een andere richting brengt, n.l. hoeveel dochters had Dakșa (een der genoemde Brahmarsii's)?

Zoo luidt in groote trekken het begin van het werk en in dezen trant gaat het voort, totdat aan het einde Dṛdhasyu lang niet aan het woord komt en na de uiteenzettingen van Agastya over het groote belang van de handhaving van de vier standen en de vier

1) Behalve de tekst-editie vergelijke men het overzicht bij Dr. Th. G. Th. Pigeaud, De Tantu Panggělaran, Diss. Leiden, 1924, pp. 319-325.

D1. 92. 
levensperioden het werk ophoudt, zonder dat hetzij z'n zoon, hetzij Agastya zelf nog genoemd worden; van hun tweegesprek wordt geen melding meer gemaakt: het Agastyaparwa houdt plotseling op, de handschriften doen nog slechts hun colophontes volgen.

Het is duidelijk, dat we het werk als het ware in paragrafen kunnen verdeelen, en dat de vragen van Dṛ̣hasyu ons een zeer bruikbare indeeling aan de hand doen. Gaan we hiertoe over, dan blijkt dat de inhoud kan worden samengevat als volgt:

1. inleiding, Agastya en Dṛ̣̂hasyu worden ons voorgesteld; zij voeren een gesprek;

2 enz. gesprek: vragen van Dṛ̣hasyu; antwoorden en uitleggingen van Agastya;

2. over het begin der wereld, enz. (zie boven);

3. „, het ontstaan der Brahmarși's en der Manu's;

4. ,, de Manwantara's ;

5. „, de dochters van Dakṣa; met wie ze huwen; hun kinderen, enz. enz.;

6. wat de oorzaak is, dat men hetzij in den hemel, hetzij in de hel komt; drie soorten zonden worden onderscheiden; aan bijzondere gevallen worden de gevolgen van het begaan van zonden gedemonstreerd; d.w.z. de gevolgen in 'n volgend leven;

7. over de andere gevolgen van het begaan van zonden; de tocht van den ătma na den dood naar hemel of hel; de pijnigingen in de hel tot de wedergeboorte in een staat overeenkomstig het vroegere gedrag; over tapas, yajña en kīrti; over de verschillende soorten van offers; over de wedergeboorte op aarde van hen die gedurende een zekeren tijd in den hemel geweest zijn,

7a. uitvoerig toegelicht met voorbeelden; zonder dat Dṛ̣hasyu een nieuwe vraag tot hem richt gaat Agastya daarna over tot de behandeling van de nog niet besproken dochters van Dakșa, n.l. die dertien, welke met Kaçyapa huwden; de oudste, Aditi, kreeg twaalf kinderen, die worden opgenoemd;

8. naar aanleiding hiervan vraagt Dṛ̣hasyu, waarom de kinderen van Aditi goden waren; dit lag, expliceert Agastya, aan haar aard, haar karakter; soorten van karakters bij goden en

8a. saptarși's; zonder onderbreking door den zoon, gaat hij over tot de kinderen van Kaçyapa bij Dakșa's andere dochters en de zich hieraan vastknoopende genealogieën; eenige uitweidingen: Indra doodt Prahlāda, wil het tweede kind van Diti in den moederschoot dooden, krijgt den naam Puramdara, zijn 
brahmahatyā belet hem in den hemel terug te keeren; explicatie van brahmahatyā of bhrūnaha; hoe het verder met Indra gaat; zijn brahmahatyā valt als een draad op aarde; waar deze

8b. brahmahatyā op aarde in aanwezig is; enz.; wederom gaat Agastya daarna over tot een voortzetting van de behandeling der genealogieën ;

9. na een vraag van z'n zoon, waarom Diti's kinderen Daitya's waren, verklaart Agastya dit uit den aard, het karakter van Diti; de Daitya's worden nu met goden, menschen enz. vergeleken ten opzichte van hun beheersching der șaḍarga;

9a. zonder interruptie wordt de bespreking van den geslachtsboom voortgezet ;

10. naar aanleiding van de vraag van Drdhhasyu, waarom Prawā tot kinderen Gandharwa's kreeg wordt door Agastya weer op

10a. haar aard gewezen, hoewel nu in het kort; eveneens zeer beknopt volgt nu weer een voortzetting van den geslachtsboom;

11. na een vraag van Dṛ̣̂hasyu, waarom Winatā Garựa tot zoon

11a. had, wordt weer stilgestaan bij den aard van Winatā; daarna volgt de vermelding van Kadrū's kroost;

12. na Dṛ̣̂hasyu's informatie, wat de reden was, dat Kadrū nāga's tot kinderen had, wordt ook haar karakter beschreven; hierna volgt weer een gedeelte der genealogie; wanneer Agastya de Yakșa's noemt,

13. volgt de vraag van z'n zoon, waarom deze de schatten bewaakten; hierop legt Agastya dit uit; hun aard wordt beschreven; ze bewaken ook Çrī; het karnen van den oceaan wordt vermeld; het betoog komt op de șaḍwarga die door den mensch overwonnen dienen te worden; de șaḍarga hebben hun oorsprong in het antahkarana;

14. Dṛ̣hhasyu vraagt, hoe de ahĕñkāra te niet gedaan kan worden; door yoga, is het antwoord; er volgen nog andere beschouwingen, n.l. over de trikāya paramārtha;

15. voortzetting der genealogie; de kinderen van Pulaha zijn dieren; dit wordt omstandig verhaald; een beschouwing volgt; hieraan worden leeringen vastgeknoopt omtrent de oorzaken ervan, dat men bij wedergeboorten steeds lager kan dalen;

16. Dṛdhasyu vraagt naar de verlossing van laag-gezonkenen; dit

16a. legt Agastya uit; daarna vat hij de genealogie weer op en komt dan tot eenige opmerkingen over wat men aan z'n vader, 
wat aan z'n moeder ontleent, en over wat men bij de geslachtelijke vereeniging in acht moet nemen;

17. na een desbetreffende vraag van z'n zoon deelt Agastya de overige familie van Bhrgu, eveneens een schoonzoon van Dakṣa, mee; o.a. maakt hij gewag van Aurwa en Paraçu-Rāma;

18. vervolgens spreekt Agastya over de bedoeling van ParaçuRāma; hij wilde de hoogste der zestien tattwa's, de verlossing, bereiken; schildering der verschillende graden en van den yoga, dien men moet verrichten om een hoogeren graad te bereiken;

19. over de voorwaarden, die vervuld moeten worden om dewatā te worden; allereerst drie brata's vervullen (akrodha, alobha, çokawarjita);

20. kan men dit niet, dan is er een andere weg, n.1. een sĕmbah te maken voor een pandita en zich door hem laten wijden; over de eigenschappen die een wiku moet bezitten wil hij geschikt zijn om tot guru te worden genomen; uitvoerig over wijding (dīkṣā) en verwante onderwerpen;

21. over het nageslacht van Angira bij een andere vrouw, Surūpā, dochter van Marīci ;

22. over de verdere familie van Pulastya, die ook gehuwd was met Ilā, Tṛnawiṇụu's dochter; hieraan sluiten andere genealogieën aan;

23. naar aanleiding van het noemen van de namen van Raghu, Dilīpa, Rāmabhadra e.a. door Agastya vraagt Dṛ̣hasyu, wat het gedrag was van koningen als de genoemde, waardoor de wereld gelukkig was; het geluk van de wereld werd veroorzaakt door het volgen van den dharma, en wel door ieder van de caturwarna ; hierover wordt uitgeweid.

Zooals men ziet wordt de uiterlijke vorm, die van een vraaggesprek, volgehouden, behalve, zooals reeds opgemerkt, geheel aan het slot, waar we nog gaarne een korte mededeeling zouden vinden, al was het maar, dat vader en zoon hier hun gesprek staakten. Het werk heeft dus een raam, een omlijsting, n.l. de samenspraak tusschen Agastya en Dṛhhasyu; de 22 vragen, die de laatste stelt zijn telkens aanleiding tot het meedeelen van episoden. Zonder moeite kan men nu daarbij opmerken, dat deze invoegingen in de omlijsting van het vraaggesprek, afgezien van een inleidend gedeelte ( $\$ \S 2-4)$, op zichzelf tot op zekere hoogte een omlijsting met ingevoegde episoden vormen. Door nagenoeg het geheele werk, vanaf $\S 5$, strekt zich uit een behandeling van het geslacht van de brahmarși's, speciaal 
van Dakșa en z'n nakroost. Doch in deze, door Agastya beschreven, ontwikkeling der familie-verhoudingen zijn telkens ingezet stukken van anderen aard: de genealogische deelen omlijsten als het ware beschouwingen, soms zelfs korte tractaten, over theologische kwesties, leeringen, opvattingen. Eenige malen wordt naar aanleiding van het vermelden van een naam in de genealogie even bij den drager daarvan stilgestaan, wordt in korte trekken een legende, de geschiedenis van zoo'n persoon in de herinnering teruggeroepen, doch deze episoden maken slechts een klein gedeelte uit van de invoegingen in de voortrollende ontwikkeling der geslachts- en familierelaties: het grootste deel bestaat uit theologische tractaatjes.

De inhoud van het werk is dus van gemengden aard; voor afwisseling is zorg gedragen.

Voor we er echter toe overgaan deze beide hoofdbestanddeelen nader te beschouwen, moeten we de aandacht even vestigen op de vele kortere en langere stukjes Sanskrit, die door het geheele werkje te vinden zijn. Het begint met een, helaas zeer corrupt, Sanskrit vers, waarop geen Oud-Javaansche vertaling of paraphrase volgt, Drdhasyu wordt ons voorgesteld in een gedeeltelijk met eenige zekerheid te herstellen çloka, waarna wel een vertaling komt; zoo goed als steeds is een vers of een deel van een vers in het Sanskrit de vorm, waarin de vraag of het begin van een vraag van den leergierigen zoon gegoten is. Ook Agastya vangt de onderdeelen van z'n betoog gaarne aan met eenige woorden in de heilige taal, bovendien kruidt hij er af en toe z'n uiteenzettingen mee; als regel volgt een vertaling. Deze eigenaardigheid nu deelt ons werk met een aantal andere geschriften der Oud-Javaansche literatuur, b.v. de boeken van het Mahābhārata en het Brahmāṇda-Purāṇa. De inkleeding van de stof noopt ons echter tot het stellen van eenige vragen.

Hoe verhoudt zich het Agastyaparwa in stof en in vorm tot de andere Oud-Javaansche proza-werken? Is het een bewerking van een Sanskrit tekst? Is het een, hetzij in Voor-Indië hetzij op Java vervaardigd, compleet geschrift, of is het een onderdeel van een grooter werk? Stemt de inhoud geheel en al overeen met wat andere geschriften, die over dezelfde of verwante onderwerpen spreken, ons leeren? Zijn er punten van verschil, hoe zijn die te verklaren? Is er onder de hoofdzakelijk Voor-Indische stof ook Javaansche invloed te onderkennen? Zijn de stukjes Sanskrit citaat, en zoo ja is hun herkomst te identificeeren? Deze vragen en andere kunnen we stellen; het geven van antwoorden is minder eenvoudig. 
Wat de behandelde stof aangaat, voor de uitvoerig uiteengezette genealogie hebben we al terstond een parallel in het Oud-Jav. Brahmāndạ-Purāna ${ }^{1}$ ). Meer moeite kost het bij de theologische onderdeelen spoedig parallel-plaatsen te vinden. Het karakter daarvan is zeer bekend: in vele werken der Sanskrit letterkunde vindt men overeenkomstige beschouwingen, vaak van zeer verregaande gelijkenis. Dharmaçāstra's, het epos, purāṇa's, de zich daarbij aansluitende sectarische literatuur bevatten vele parallellen. Op Java vinden we in teksten als de Sang hyang Kamāhāyanikan, de Korawāçrama en andere menige passage, die in aard en karakter overeenstemt met episoden uit het Agastyaparwa.

Van belang voor de wijze van ontstaan en herkomst van het werkje kan het zijn te weten hoe de theologische gedeelten in de genealogischlegendarische zijn ingevoegd. Krijgt men den indruk, dat in een oorspronkelijk genealogische verhandeling later tekstdeelen van geheel anderen aard zijn geinterpoleerd? Is het werk reeds van den beginne een compilatie geweest? Of zijn er overgangspassages, waar sporen zijn te ontdekken van latere ineenvoeging? Volgt het eene tekstdeel ongedwongen op het andere of niet?

Behandelen we achtereenvolgens de omlijsting, of beter de inkleeding: het vraaggesprek; het genealogische gedeelte; de theologische tractaatjes; de stukjes Sanskrit.

De figuur van Agastya is over-bekend, zooveel in Indië als op Java. In meer dan één Oud-Javaansch literatuurproduct wordt gewag van hem gemaakt ${ }^{2}$ ), op inscripties wordt hij vaak genoemd ${ }^{3}$ ), als heilige vereerd ${ }^{4}$ ).

In ons werk treedt hij echter op als de verteller van de behandelde stof. Dat een werk wordt ingekleed als een vertelling is niet vreemd, ook de parwa's van het Mahābhārata b.v. en het Brahmāṇụa-Purāṇa worden verteld, al is het dan aan een talrijker gehoor. Ook daar is het op verzoek van het gehoor, dat de stof verhaald wordt. En wat de onderbrekingen en vragen van Dṛ̣hasyu betreft, vinden we b.v. in het Adiparwa niet op menige plaats een pauze in de uiteenzettingen van Ugraçrawa, en vraagt dan Çonaka niet om het verhaal

1) Zie vooral pp. 58 en volgende in mijn editie.

2) Men zie de, niet geheel volledige, verzameling van plaatsen bij Dr. Poerbatjaraka, Agastya in den Archipel, hfdst. III, pp. 32-42. Hij komt in de O.-J. literatuur evenwel niet zoo vaak voor als we wellicht zouden verwachten.

3) Poerbatjaraka, o.c., hoofdstuk IV.

4) Vgl. Krom, Hindoe-Jav. Gesch. ${ }^{2}$, en $=$ Inl. H.-J. Kunst, Registers s.v. 
voort te zetten of om nadere inlichtingen over het een of het ander ? ${ }^{1}$ )

Dr. Pigeaud, die reeds, voor zoover hem mogelijk was, eenige opmerkingen over den inhoud van ons geschrift heeft gemaakt ${ }^{2}$ ), is, constateerende dat ,de hier gegeven voorstellingen... over het algemeen zeer goed (blijken) overeen te stemmen met die in andere ons bekende geschriften uit d'oudere Javaansche literatuur" van oordeel, dat 't zeer belangwekkend zou zijn, ,indien 'n Skrtt werk aangewezen kon worden, waarop 't Angastyaparwwa (sic) berust...". Zeker, dat zou het, en het spijt mij, dat ik er tot nog toe evenmin in geslaagd ben een Voor-Indisch voorbeeld voor onzen tekst te vinden, d.w.z. een geschrift, waartoe het Oud-Jav. Agastyaparwa zich verhoudt als b.v. de boeken van het Mahābhārata tot het VoorIndische Mahābhārata. Voegt Dr. Pigeaud aan zijn opmerkingen echter toe, dat in de Sanskrit letterkunde alleen een Agastyasamhitā bekend schijnt te zijn, dat als een onderdeel van het Skandapurāna geldt ${ }^{3}$ ), dan moet ik deze meening bestrijden. Er zijn vele geschriften bekend behalve het genoemde, waarin Agastya optreedt, hetzij als verteller, hetzij als ondervrager, hetzij als zoogenaamd auteur. En ofschoon, zooals gezegd, er geen enkel bij is, dat als prototype kan gelden voor het Oud-Jav. Agastyaparwa, lijkt het mij de moeite waard, even onze aandacht te bepalen bij enkele dezer literatuurproducten, niet alleen wegens den persoon van den verteller of ,auteur”, maar ook wegens de verwantschap van inhoud die deze geschriften met het onze veelal vertoonen. Door een aantal (naar volledigheid is niet gestreefd) dezer teksten de revue te laten passeeren kan het ons duideiijker worden in welk geheel het Agastyaparwa moet worden gezien, met welke afdeeling van de Indische letterkunde het 't nauwste verbonden is.

Dat wijzen en rụi's als Agastya, Bhṛgu, Nārada, Vasișța, Yājñavalkya en vele anderen in Indische werken als verhaler optreden is te bekend om te vermelden. Dat ook aan Agastya reeds Vedische hymnen worden tcegeschreven ${ }^{4}$ ), dat zijn naam van de vroegste tijden in allerlei verhalen wordt genoemd behoeft ons niet bezig te houden ${ }^{5}$ ).

1) Vg1. b.v. p. 18 , p. 23 , p. 29 , p. 46 , ed. Juynboll.

2) De Tantu Panggělaran, p. 325.

3) Hij citeert Winternitz, Gesch. der ind. Lit. I, p. 476.

4) N1. Rg-Veda, I, 165-191.

5) Zie b.v. E. Sieg, Die Sagenstoffe des Rgveda und die indische Itihāsatradition, Stuttgart, 1902, pp. 105-129. - Een verzameling wetenswaardigheden over Agastya: Poerbatjaraka, Agastya in den Archipel, hfdst. I, pp. 1-14. - 
In het epos is hij goed bekend: het Mahābhārata ${ }^{1}$ ) verhaalt de geschiedenis van zijn huwelijk met Lopāmudrā, de dochter van een koning van Vidarbha ${ }^{2}$ ), en de geboorte van zijn zoon Dṛ̣̂hasyu ${ }^{3}$ ), alsmede vele legenden die over hem in omloop zijn ${ }^{4}$ ).

Voor ons doel is dit van minder belang. Belangwekkender is de rol, die hij in het Rāmāyaṇa speelt. De geschiedenis van zijn wonderbaarlijke geboorte ${ }^{5}$ ), zijn avonturen met Tățakā en Mārīca ${ }^{6}$ ) en andere legenden kunnen we voorbijgaan; meer interesseert ons de passage in het Araṇya-kāṇ̣a ${ }^{\tau}$ ), waar Rāma en de zijnen een bezoek brengen aan Agastya's kluizenarij; ze laten zich aandienen, en worden door den heiligen man vriendelijk en gastvrij onthaald, hij geeft Rāma waardevolle geschenken en wijst hem een woonplaats, Pañcavatī, aan. Is dit dus een bezoek, den ṛsi gebracht, elders ${ }^{8}$ ) in hetzelfde epos komt Agastya aan het hoofd van ṛ̣i's uit alle streken tot Rāma, wanneer deze de overwinning op zijn vijanden heeft behaald; zij prijzen hem dan, vooral omdat hij Indrajit heeft onderworpen. Op Rāma's vraag, waarom Indrajit dan wel sterker is dan de andere rākṣasa's, vertelt Agastya een verhaal om dit te verklaren ${ }^{9}$ ). Rāma vraagt $\operatorname{verder}^{10}$ ) naar den oorsprong van de rākṣasa's, en hierop volgt een uitvoerig relaas van genealogiën en geschiedenis van het geslacht der rākșasa's, vooral van DaçagrīvaRāvana en zijn naaste familie. Bij wijze van aanhangsel krijgen we nog het verhaal van de jeugd van Hanuman te hooren. Dit alles wordt door Agastya verteld, enkele malen door Rāma nader ondervraagd $\left.{ }^{11}\right)$; tenslotte nemen Agastya en de andere rși's afscheid ${ }^{12}$ ).

Het is evident, dat dit geheele gedeelte van het Rāmāyaṇa (7, a. 1-36) een invoegsel is; bij 7, a. 37 wordt het Rāma-verhaal weer

Over de „Agastyas” der traditie: F. E. Pargiter, Ancient Indian historical tradition, pp. 238-240.

1) Vgl. Holtzmann, Der heilige Agastya nach den Erzählungen des Mahãbhārata, Z. D. M. G. 34 (1880), 589-596.

2) Vg1. Mbh. 3, 97, 8570 vlgg.

3) Vgl. Mbh. 3, 99, 8637 vlgg.

4) We zouden nog kumnen opmerken, dat Mbh. 13, 84, 38 Rãma, Jamadagni's zoon, hem om raad komt vragen.

5) Zie Rām. 7, a. 57.

(6) Zie Rām. 1, a. 25.

`) Rām. 3, a. 11-13.

s) Rãm. 7, a. 1.

9) Rām. 7, a. 2 .

10) Rām. 7, a. 4.

11) Zie $\operatorname{nog} 7$, a. 31 ; a. 35,1 .

12) Rām. 7, a. 36 . 
voortgezet (n.l. met de beschrijving van den ochtend, volgende op Rāma's wijding), waar het zesde boek was geeindigd (de plechtige wijding van Rāma tot koning) ${ }^{1}$ ). Dit geheele gedeelte, 7, 1-36, dat met het Rāma-verhaal slechts uiterlijk in eenig verband staat en dat door Jacobi Rāvaneieis wordt genoemd ${ }^{2}$ ), is naar z'n inhoud een aaneenrijging van genealogieën en ,oude geschiedenis”, zooals men er vele vindt in het Mahābhārata en de Purāṇa's, dus kort gezegd ,puranisch”, naar den vorm, naar het uiterlijk een door vragen onderbroken verhaal van Agastya, een "Agastyaparva”.

Elders in hetzelfde Uttara-kāṇ̣a is Agastya weer de verteller van een episode ${ }^{3}$ ). Hij verhaalt een ontmoeting van hemzelf en den koningszoon Çveta, die door askese den hemel bereikt had, in een verlaten woud. Op Rāma's vraag, waarom dat woud zoo verlaten was, is Agastya's beantwoording een uiteenzetting over Daṇ̣a, een afstammeling van Manu, die Uçanas tot purohita nam, doch zich aan diens dochter Arajā vergreep. Uçanas vervloekte hem daarop: Danḍa en z'n gansche land zouden tot asch vergaan; het land werd daarop het Daṇuaka-woud. Rāma keerde, nadat hij dit verhaal gehoord had, naar Ayodhyā terug. Wederom dus een door genealogieën ingeleid brok oude geschiedenis, wederom een puranisch verhaal.

In de purāna-edities ontmoeten we Agastya's naam meermalen. Vooreerst natuurlijk in verband met de verhalen, die van hem in omloop zijn, zijn breideling van het Vindhya-gebergte ${ }^{4}$ ), z'n tocht

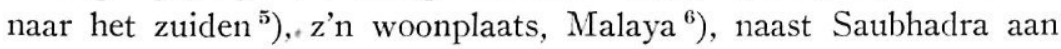
den Zuidelijken Oceaan, die bij den berg Vaidūrya, die in het gebied der Pāṇ̣̂ya's ${ }^{7}$ ); dat hij askese verricht en daarmee Çiva verheugt ${ }^{8}$ ), enz. Dan - en daarbij moeten we even stilstaan - vinden we hem ook hier als deelgenoot in een tweegesprek, in 'n vraaggesprek, hetzij als autoriteit, als verteller, hetzij als belangstellende, als leergierige.

In het Padma-Purāna bevindt zich een passage ${ }^{9}$ ), die in het oog vallende overeenkomst vertoont met het zoo juist genoemde begin

r) Rām. 6, 128.

2) H. Jacobi, Das Rāmāyaṇa, p. 189, n. Zie ook over dit gedeelte in het epos, ibidem, pp. 27 vlgg. - In de aanteekeningen worden de in onzen tekst besproken, ook in deze Rāvaṇeis voorkomende onderwerpen aangegeven.

8) Rām. 7, a. 77-82.

4) Vgl. Brahma-Purāṇa, a. 119.

5) Brahma-Pur. 85, 8 vlg.; 159, 10 vlg. e.a.

(j) Vāyu-Pur. 48, 23 vlg. e.a.

7) Plaatsen uit het Mbh. geciteerd bij Pargiter, o.c. p. 240.

8) Saura-Pur. 67, 9.

9) Pātālakhaṇda, begin ; cf. Wilson, Ess. Lit., I, p. 48. 
van het VIIe boek van het Rāmāyaṇa. Hier beschrijft de slangendaemon Çeșa aan Vātsyāyana de terugkeer van Rāma naar Ayodhyã en komt zoo te spreken over het bezoek dat Agastya den overwinnaar Rāma bracht; de heilige man vertelt dan over Rāvaṇa's lotgevallen, in aansluiting bij de Rāvaneïs uit het epos, doch we vinden hier de uitbreiding, dat, daar Rāvaṇa eigenlijk van geboorte een brahmaan was, en Rāma dus een groote zonde begaan had met hem te dooden, de koning om deze schuld weer goed te maken een açvamedha, paardenoffer, moest houden.

Een uitvoerige Agastya-vertelling bevat ook het Varāha-Purāna ${ }^{1}$ ). Viṣnu verhaalt in dit werk in zijn gedaante van everzwijn (varāha) onder meer een ontmoeting van Bhadrāçva en Agastya: de eerste grijpt deze gelegenheid aan om den heiligen man te ondervragen ${ }^{2}$ ): hij vangt aan met te vragen door welke werken de keten der wedergeboorten wordt onderbroken, door welke werken de van lichamen voorziene wezens geen pijnen lijden. Agastya deelt daarop ${ }^{3}$ ) de interessante geschiedenis van koning Paçupāla mede, die in oude tijden op reis om den Oostelijken Oceaan te zien in een woud kwam, waar slangen huisden, die hem den weg versperden; het vervolg van deze legende, waarin ook een ges!achtsregister is opgenomen, doet voor ons doel weinig ter zake. Ook hier zien we, dat van tijd tot tijd de hoorder tot den verteller een nieuwe vraag richt ${ }^{4}$ ). De onderrichtingen gaan voorts o.a. over de vereering van Viṣnu, twaalf vrata's, waardoor deze god kan worden gewonnen, worden in de volgende adhyāya's beschreven; daarna vernemen we een legende over Nā$\left.\operatorname{rada}^{5}\right)$; na eenige andere informaties stelt Bhadrăçva vragen over het gedrag der standen in de verschillende yuga's ${ }^{6}$ ), over de reiniging wegens omgang met een vrouw van een anderen stand, over ongeoorloofde sexueele vereeniging (agamyāgamana) ${ }^{7}$ ). Vervolgens moet de heilige een en ander over zich zelf vertellen: eerst een interessant avontuur ${ }^{8}$ ), daarna een verhaal omtrent een verschijning der goden voor hem, waarbij Rudra verklaart, dat Nārāyaṇa de voornaamste humner is ${ }^{9}$ ); hieraan worden allerlei leeringen toegevoegd, die wij

1) Varāha-Purāṇa (Bibl. Indica), adhy. 51 enz.

2) Varāha-Pur. 51, 6.

3) Varāha-Pur. 51, 9; 52.

4) Vgl. adhy. 53, 1; 54, 1; 55, 31 e.a.

5) In adhy. 67 .

(i) Varāha-Pur. 68, 2.

7) Ibid. 68, 7.

s) Adhy. 69 .

9) Adhy. 70 . 
onvermeld kunnen laten. Afgezien van het groote verschil in inhoud met het Oud-Javaansch Agastyaparwa zou men dit gedeelte van het Varāha-Purāṇa een Agastya-tractaat, een Agastya-parva kunnen noemen.

Een werk, dat zich uitgeeft als een deel van het Brahma-Purāṇa en wel als het Uttara-khanḍa, doch dat los staat en in onderwerp geheel afwijkt van genoemden tekst ${ }^{1}$ ) is een omvangrijke vertelling van Çaunaka aan Çatānīka, echter voorgesteld als een weergave van een vroeger plaats gehad hebbende vertelling van Agastya aan den wijze Supratīka. Het verhaal begint met Brahmā's liefde voor Sarasvatī en de geboorte van hun zoon Sumṛịka, die twist krijgt met z'n vader en hem dan uit den hemel verdrijft. Deze sticht een stad aan de Balajā-rivier, van welke rivier de heiligheid dan verder in het werk geprezen en geroemd wordt. Ofschoon er nog een aantal legenden in voorkomen, behoort het toch tot de categorie der māhātmya's, lofzangen, verheerlijkingen op heilige oorden en dergelijke.

Een merkwaardig geschrift, eveneens op de gewone wijze ingekleed, is het Lalitopākhyānam, het verhaal van Lalitā, d.w.z. Durgāi, Pārvatī, Çiva's wederhelft. Voor zoover mij bekend is, is de inhoud van dezen tekst nergens eenigszins uitvoeriger meegedeeld dan met een paar regels ${ }^{2}$ ). Het werk stelt zich voor als een deel van het Brahmāṇ̣a-Purāṇa, de onderschriften der hoofdstukken doen dit duidelijk uitkomen: zoo luidt dat onder het eerste: iti çrîbrahmändamahāpurāne uttarabhāge hayagrī̄āgastyasanı̄āde lalitopākhyāne agastyayāträjanārdanā̃irbhāvo nāma pañcamo 'dhy'āyaḷ, volgens de in de Brahmāṇda-Purāṇa-editie gedrukten tekst ${ }^{3}$ ). Aan de laatste woorden ziet men, dat de nummering der adhyāya's doorloopt; zonder onderbreking volgt na het onderschrift van Bmḍ. Pur. 3, a. 4: crīganeçāya namah | atha şrīlalitopākhyānaṇ prārabhyate $\mid$. Het is dus een aanhangsel bij genoemd Purāna, dat aan den naast-verwanten ${ }^{4}$ ) tekst, het Vāyu-Purāna, niet is toegevoegd. Van de reeds besproken teksten onderscheidt het zich in zooverre, dat Agastya

1) Zie over dit werk H. H. Wilson, Essays.... on subjects connected with Sanskrit literature, collected and edited by Dr. Reinhold Rost (London 1864), I, pp. 19-21.

) En wel bij Wilson-Hall, The Vishṇu Purāṇa, I, p. LXXXVI, en in handschriften-catalogi; vgl. Eggeling. Catalogue of the Sanskrit manuscripts in the Library of the India Office, VI, Londen, 1899, p. 1244, no. 3431.

3) Çri-Venikațeçvara, 1913.

4) Vgl. W. Kirfel, Das Purāı̣a Pañcalakșaṇa, Bonn, 1927, pp. X vlgg., en J. Gonda, Het Oud-Javaansche Brahmāṇda-Purāna, Batavia, 1932, pp. 15 vlg. 
hier niet de verteller, doch de ondervrager is; evenwel wordt hem door den verhaler, evenals aan zijn vorige hoorders, op het hart gedrukt de onderrichtingen onder alle schepselen te verbreiden: bhavadbhih sarvabhūtānā!̣ gurubhūtair mahātmabhį̣ | mamopadeço lokeșu prathito 'stu varo mama $\|(1,17=$ Bmọ. Pur. 3, 5, 17). Het zou mij te ver voeren, een inhoudsopgave van dit geschrift mee te deelen; op het begin wil ik evenwel wijzen. Agastya ${ }^{1}$ ), zoo luidt dit, begeeft zich op reis om tīrtha's en āyatana's, bedevaartplaatsen en heiligdommen te bezoeken; hij komt dan in Kāñcī (tgw. Conjeeveram), waar hij pūjā verricht, tengevolge waarvan Viṣnu hem verschijnt in de gestalte van Hayagriva ${ }^{2}$ ) en hem een wensch toestaat. Agastya richt dan allerlei vragen tot hem.

In de lange beschrijving van de daden van Rāma, zoon van Jamadagni, die in het Brahmāṇ̣a-Purāna voorkomt, vinden we ook een bezoek van dezen held aan Agastya om toovermacht van dezen heilige te erlangen ${ }^{3}$ ).

Een ander Agastya-gesprek, dat beweert deel uit te maken van het Brahmāṇ̣a-Purāna is de Agastya-sūta-samvāđa, ,onderdeel van het Kṣetrakhaṇụa van dit Purāna" ${ }^{4}$ ).

Als onderdeel van het Brahmakaivarta-Purāna vinden we een Agastya-Çaunakasạ̣vāda vermeld ${ }^{5}$ ).

Voorts is er een werk onder den naam Devī-Purāṇa, ,a semitantric Purāna, glorifying the power of the great goddess; and professing to be revealed by Agastya to Nripavāhana, and related to the Rishis by the muni Vaçishțha" ${ }^{6}$ ).

Een „Agastyasmrti” ,lays down rules for the acts and religious rites which a Brahman should perform from the time he rises from his bet to the time he goes to sleep. It is attributed to Agastya" ${ }^{7}$ ).

Agastyasūtras bestaan er, ,which expound the bhakti of the Devi

1) Deze wordt hier genoemd (vs. 3): Agastyo nāma devarșir vedavedā$\dot{n}$ gapāragah̆ | sarvasiddhāntasārajūo brahmānandarasātmaką̣ı ||

2) O.a. een, b.v. in den Harivamça meermalen genoemde, asura, die den Veda stal en daarom door Viṣnu werd gedood; vervolgens een verschijningsvorm van Vișnu zelf : in lateren tijd, wanneer men meer avatāra's kent, een hiervan; vg1. E. Abegg, Der Messiasglaube in Indien und Iran, Berlijn-Leipzig, 1928, pp. 41, 52 e.a.

3) Bmḍ. Pur. 2, 35, 47 vlgg.: zie ook boven, p. 344 11. 4.

4) Eggeling, o.c., VI, vermeldt een Mallāpurīmāhātmya, als deel van dezen saṃvãda (p. 1250, no. 3443).

5) Sarpapurakshetramāhātmya ... forming adhyãyas $52-56$ of the ... B-P., zie Eggeling, o.c., VI, p. 1238, no. 3417.

6) Eggeling, o.c., VI, p. 1205 , no. 3362 .

7) A triennial Catalogue of mss., Madras 1913/4-1915/6, p. 1309, no. $994 \mathrm{~h}$. 
Bhāgavata" ${ }^{1}$ ). Albērūni maakt ${ }^{2}$ ) gewag van ,the book Agastyamata, composed by Agastya, treating of the subject that in all investigations we must use the apperception of the senses as well as tradition".

Een werk waarvan het onderwerp wordt opgegeven als „dharma”, het Citrakūṭamāhātmya, heeft als auteur Agastya ${ }^{3}$ ); elders ${ }^{4}$ ) wordt een geschrift van dezen naam genoemd, ,a treatise... in commendation of pilgrimages to the holy places in the Bundelkand country, hallowed by Rāma's stay during his exile. The work purports to be revealed by Atri to king Bharata; and then again by Bhuçundi to Çānḍilya, or by Agastya to Sutikshṇa; and claims to belong to the Ádirāmāyaṇa, and to have been composed by Vālmīki himself".

Van een samenspraak van Agastya met z'n broeder Sutikṣ̣na o.a. uit het Rāmāyaṇa bekend, waar Rāma c.s. hem bezoekt ${ }^{5}$ ) — vinden we vaker gewag gemaakt. Zoo is er een geschrift ${ }^{6}$ ), waarvan de colophon luidt: ,iti şrībrahmānde agastyasamhitāyām sutīkṣ̣nāgastyasamvāde rāmamānasikapüjāvidhānam nāma pañcatriṃ̧o 'dhyāyaḥ", dus één adhyāya uitmaakt van een tot het Brahmāṇda-Purāṇa behoorende Agastyasamhitā. Men is geneigd hier in de eerste plaats te denken aan een anderen naam voor het boven besproken Lalitopākhyāna, dat men desnoods wel naar Agastya zou kunnen noemen, doch dit komt niet uit. Daar verder een Agastyasamhitā en dan nog wel van den omvang van minstens 35 adhyāya's in de editie van genoemd Purāna niet voorkont, dienen we dezen tekst te beschouwen als een van de vele geschriften, die zeggen deel uit te maken van, te behooren tot een of ander purāna. Dat er op deze wijze veel meer teksten tot de verschillende vertegenwoordigers van dit literatuurgenre behooren, dan uit de edities en volledige handschriften blijkt wordt ons, wanneer we de catalogi der manuscripten doorbladeren, spoedig duidelijk ${ }^{7}$ ). En dat er onder deze teksten zijn, die zich beroepen op de autoriteit van Agastya of hem hun auteur noemen

1) Farquhar, Outline, p. 269; vgl. p. 359; Sanskrit Journal of Madras, III, 1897, (mij niet toegankelijk).

2) Albērūni, India, p. 64; Eng. vert. van Sachau, I, p. 132.

$\left.{ }^{3}\right)$ R. B. Hiralal, Cat. of Skt. and Prākr. mss. in the Central Provinces and Berar, no. 1681.

4) Eggeling, o.c., p. 1394, no. 3704 .

5) Rām. 3, a. 7 vlgg.

$\left.{ }^{6}\right)$ Zie: A descriptive Catalogue of the Skt. Mss. Madras, XVI, p. 6297, no. 8682 .

¡) Vgl. b.v. voor het Brahmāṇḍa-Purāṇa de lange lijst, die Aufrecht, Catalogus Catalogorum, s.v. biedt. 
kan ons in 't minst niet bevreemden ${ }^{\mathbf{1}}$ ). Evenmin echter de omstandigheid, dat we teksten over dezelfde of ongeveer dezelfde onderwerpen op naam van een anderen autoriteit als behoorende tot hetzelfde Purāṇa vinden vermeld; als voorbeeld kan hier dienen een geschrift ,in praise of Rāma... taken from Hiraṇyagarbhasạ̣hitā of Brahmāṇ̣a-Purānạ” ${ }^{2}$ ).

Aan den anderen kant is het volstrekt niet ongewoon, wanneer we denzelfden naam aan twee of meer verschillende werken vinden toegekend ${ }^{3}$ ). Om ons te bepalen tot de Agastyasaṃhitā, die hier reeds ter sprake kwam, - en nu kom ik terug tot m'n boven ${ }^{4}$ ) gemaakte opmerking over de meening van Dr. Pigeaud - dezen titel vinden we meermalen genoemd. Bij voorbeeld is, weer met vermelding van z'n broer Sutikș̣na, een dusgenaamde tekst $\left.{ }^{5}\right)$ : „sutīkṣnamunisaṇlnidhau agastyasya harapārvatīsanvō̄dakathanam", tantrisch van genre.

Zeer vaak wordt in den colophon van een Agastyasaṃhitā vermeldt, dat de tekst deel uitmaakt van het ontzaglijk uitgebreide conglomeraat, het Skanda-Purāṇa, b.v. iti skānde purāne agastyasaṇhitāyām brahmavasișthasaṇıāde ... pārameçvareṇa proktam rāamāyaṇamāhātmyaṇ nāma $\left.\ldots{ }^{6}\right)$. Op den voorgrond treedt in die teksten de Rāma-vereering ${ }^{\top}$ ), al geven geschriften met anderen inhoud zich ook uit als deelen van deze Agastyasamhitā's. Zoo vinden we onder de meer dan tweehonderd „saṃhitā's” tellende lijst van literatuur van de Visnuitische secte der Pāñcarātra's ook de $\bar{A}_{\text {gastya }}{ }^{8}$ ), en wel drie werken van dien naam, een Agastya-Sutīkṣna-saṃvāda, een Agastya-Nārada-saṃvāda, en een derde. Tot

1) Nog een paar voorbeelden: Hiralal, o.c., no. 4873 en 4874 noemt een Lakșmî-stotra, attributed to Agastya, subject: dharma; occurs in ViṣhṇuPurăna". Een loflied op deze godin komt in het Viṣnu-Pur. voor (1, 9, 116 vlgg.), maar Indra houdt het.

2) Vgl. Catal..... mss..... Madras, XVII, p. 6496.

3) Zie ook F. Otto Schrader, Introduction to the Pãñcarātra etc., Madras, 1916, p. 13.

4) Zie p. 343 .

5) Catalogue of printed books and mss. in Skt.... Or. Libr..... As. Soc. of Bengal, Calcutta, 1904. - Agastya en Sutikșna bv. nog Weber, Verzeichnis Skt. Hss. Berlin, II, 1, p. 114.

6) Triennial Cat. Madras 1919/20-1921/2, p. 5629, no. 3804.

7) De laatstgenoemde tekst staat in den cat. opgegeven als commentaar op Vālmiki's Rām. Vgl. Cat. Madras, XIV, p. 5157, no. 7025 ; XVI, p. 6295 etc., no. 8678 etc.; p. 6117 , no. 8437 ; enz.; Eggeling, o.c., p. 1319 , no. 3621 , e.a.; de laatste ,inculcating the worship of Vishnu in his different forms (especially that of Rāma), as expounded by Çiva to Pārvatī, and by Agastya to Sutīkshṇa".

8) F. Otto Schrader, o.c., p. 6. 
een juister begrip van wat de aanhangers van de in deze en dergelijke teksten verkondigde leeringen onder „,sạ̣hitā” verstaan moge het volgende in herinnering gebracht worden ${ }^{1}$ ): de literatuur van Hindoeistische secten maakt onderscheid tusschen werken, die van goddelijke origine, geïnspireerd, zijn en teksten die menschenwerk zijn. De eerste soort noemt men wel samhitā's, compendia, metrische teksten, die de leeringen van de secte behandelen. De naam, waarvoor men ook wel ,tantra" vindt, moge ons eerder tot vergelijking lokken met de „Manu Samhitā” = Mānavadharmaçāstra dan met de Vedische saṃhitā's, die een geheel ander karakter dragen ${ }^{2}$ ).

Men merke nu op, dat Agastya in geschriften van verschillende secten optreedt. Met de vereering van Viṣnu vinden we z'n naam meermalen verbonden. Maar, zooals gezegd, de inhoud van tot de „Agastya-samhitā's” gerekende teksten is velerlei. Zoo vinden we b.v. teksten over prāyaçcitta (weer-goed-making, zoeningen) ${ }^{3}$ ), mudrālakṣaṇa (mudrā's: vingerhoudingen) ${ }^{4}$ ), een Prasūtigaṇ̣adoṣaçānti (,,regarding the çanti to be performed in cases of child-birth under certain asterisms considered inauspicious”) ${ }^{5}$ ), een Siddhāntaçikhāmañi (,,an authoritative account of the doctrines of Vìra-çaiva religion, given in the form of a discussion between Renuka and Agastya", ook deel van 'n Agastyasamhitā ?) ${ }^{6}$ ), een Varṣaphaṇi, als onderdeel van een Varșaganita (,,deals with the drawing of a snakelike diagram”) `), een Gaṇdanakșatraçānti (,,deals with the çānti to be performed to avert the evil effects supposed to arise when a child is born, when the moon is in the constellation Citrā, Pusya, etc., as well as when both the father and son happen to be born on the same Nakșatra") ${ }^{8}$ ), een Caturdaçīprasūtiçānti (çānti voor geboorte op den 14 en v. d. maandhelft) ${ }^{9}$ ); naast een Daçāvatārastotram $^{10}$ ) worden aan hem lofverzen op Çiva toegeschreven ${ }^{11}$ ).

Het verwondert ons dan ook niet te zien, dat hij geldt als de

1) Vgl. Schrader, o.c., p. 2.

2) Vgl. voorts beneden. Zie ook bv. in het O. J. Bmḍ. Pur., 112, 31: Brahmāṇụasañhitā.

3) Vgl. Triennial Cat. Madras 1919/20-1921/2, p. 4359, no. 2996.

4) Ibid. p. 4842 , no. 3257 .

5) Cat. mss. Madras, VI, p. 2545, no. 3384.

$\left.{ }^{6}\right)$ Ibid. X, p. 3920, no. 5119.

¡) Ibid. XXIV, p. 9113 , no. 13491.

s) Ibid. XXV, p. 9673 , no. 14443.

9) Ibid. XXV, p. 9694 vlg., no. 14477.

10) Triennial Cat. Madras, 1919/20-1921/2, p. 4734, no. 3195.

11) Bv. Agastyāștakam, Cat. mss. Madras, XIX, p. 7416 vlg., no. 10899 vlg. 
stichter van een godsdienstige richting, den dienst van Harihara ${ }^{1}$ ), welke men in teksten onder den naam Harihareçvaramāhātmya of Hariharamāhātmya vindt vertegenwoordigd ${ }^{2}$ ); hier worden Viṣnu en Çiva in hun gecombineerde gestalte Harihara vereerd; ook deze teksten beweren deel uit te maken van het Skanda-Purāna. De cultus van dezen tweevoudigen god, die ook in den Harivamça ${ }^{3}$ ) wordt bezongen, zou Agastya vanuit Kāçi verbreid hebben ${ }^{4}$ ). Interessant is ook wat van hem, volgens de inhoudsopgave ${ }^{5}$ ), verteld wordt in het z.g. „Madura-Stalla-Purāṇa”; in Çiva's paradijs, op den Kailāsa, zijn een aantal ṛși's bijeen; een hunner vertelt te Kāçî Agastya te hebben hooren spreken over een wel zeer bijzonder „Sivastallam"; op verzoek der anderen geeft hij van Agastya's woorden, ,without any further allusion to the present company" een referaat van begin tot 't einde: men had Kāçì verlaten en een bezoek gebracht aan Madurā, ,where, after bathing in the tank, and obtaining a sight of the original lingam, they received gifts from the god; and afterwards Agastyar, with each of the others, established inferior images, calling these respectively by their own names; and then went to their Tapasuvanas, or places of retirement, austerities, and meditations, according to the usage of such sages".

Deze grepen uit de menigte geschriften, die zich naar Agastya noemen of zich op zijn autoriteit beroepen, of waarin deze heilige een voorname rol speelt mogen voldoende zijn om te laten zien, in welk genre literatuur hij in de Sanskrit letterkunde optreedt. Tevens zal het ons hiermee duidelijk zijn geworden, dat een titel waarin zijn naam voorkomt op zichzelf geen nauwkeurige inlichtingen over den inhoud van het betreffende werk geeft en dat we in geen geval op grond van overeenkomst in titel aan identiteit van inhoud mogen denken. En ook de in vele der genoemde werken meegedeelde bijzonderheid, n.l. dat ze een onderdeel vormen van een of ander purāna, is ons meestal van weinig nut.

Er moge met een enkel woord aan herinnerd worden, dat Agastya

1) Zie bv. Encycl. of Rel. and Ethics, II, 789 a ; IX, 69 a ; XII, 457 b.

2) Eggeling, o.c., VI, p. 1375.

3) Adhy. 184. Op Java, vgl. Krom, Inleiding Hindoe-Jav. Kunst, II, pp. 165 vlgg. e.a.

4) Eggeling, o.c., VI, p. 1375.

5) Zie W. Taylor, Or. hist. mss. Madras, 1835, I, pp. 53 vlgg.; op p. 117 Structure of the Purānna. - Sthalapurāṇa = māhātmya, werk ter verheerlijking van een bepaalde (heilige) plaats. 
in de Tamil letterkunde een zeer voorname figuur is ${ }^{1}$ ). Hij zou, volgens de traditie, met z'n gade in het Tamil-land gekomen zijn, waar hij de taal leerde en twaalf leerlingen had. Hij zou dan de schepper van de Tamil letterkunde geweest zijn en op allerlei gebieden van wetenschap den bewoners van het land een leermeester. Er bestaat b.v. een lijst van 38 werken over allerlei onderwerpen, waarvan hij de auteur zou zijn geweest ${ }^{2}$ ). Ook in de verwante ZuidIndische literaturen speelt hij een rol. De beschrijvingen van Westersche reizigers, in allerlei opzichten zoo merkwaardig en leerzaam, bevatten zijn naam dikwijls en leggen getuigenis af van de belangrijke plaats die hij in de geesten van de Zuid-Indische bevolking gedurende eeuwen heeft ingenomen. Eén passage wil ik noemen: Ziegenbalg, sprekende over het ontstaan van 48 poëten ${ }^{3}$ ), vertelt: ,diese 48 Poeten kamen endlich aus allen Geschlechten zusammen, machten unter sich eine Gemeinschafft, giengen hin in den Berg, Bodiamámalei ${ }^{4}$ ) genant, zu dem groszen propheten Agéstier und disputireten mit ihm.... Sie sprachen: Wir wollen gerne einen Platz haben, da wir alle beysammen seyn und dociren könten. Der Agestier weiset sie nach Madurei...".

Zijn we er dus niet in geslaagd een Voor-Indisch prototype van ons Agastyaparwa te ontdekken, het hier gegeven overzicht heeft ons wel duidelijk gemaakt, tot welke categorie van literatuur de OudJavaansche tekst, ware hij een Sanskrit geschrift, zou moeten worden gerekend. Een mengsel van puranische genealogie en theologische beschouwingen vormt, zagen we, onze tekst; niet zuiver puranisch — in den meer beperkten zin — van inhoud; doch zeer wel te beschouwen als puranisch in die beteekenis, die veelomvattender is en de uitloopers mede in zich sluit. Als een brokstuk van een purāṇa -, maar tevens vertoont hij verwantschap met de bijzonder omvangrijke, doch nog zeer weinig bestudeerde literatuurgroep der

1) Ter oriënteering bv. H. W. Schomerus, Die dravidischen Literaturen, in Walzel's Handbuch der Literaturwissenschaft, pp. 273 vlg. Men zie ook de Introduction van Caldwell's bekende Comparative Grammar of the Dravidian .... Languages, en vergelijke daarbij H. Nau, Prolegomena u.s. w., Diss. Halle, 1919, pp. 23 vlgg.

2) Zie Nau, o.c., p. 26.

3) Ziegenbalg's Malabarisches Heidenthum, ed. Caland, (Verh. Kon. Ak. v. Wet.), Amsterdam, 1926, p. 169.

4) De berg Pōdiya, Pothiyam, waar Agastya tot heden toe, onzichtbaar voor gewone oogen, heet voort te leven. Zie bv. de beschrijving bij Ziegenbalg, Genealogie der malabarischen Götter, ed. Germann, Madras, 1867, p. 220.

D1. 92. 
Āgama's ${ }^{1}$ ). Āgama's zijn in de Sanskrit literatuur werken die de zich in de ontwikkeling der puranische letterkunde afteekenende lijnen terstond volgen; ze hebben een sectarisch karakter en geven in het algemeen gesproken leeringen van godsdienstigen aard. „Sie geben Belehrung über das Wesen der Welt, der Seele, der Gottheit, über Wiedergeburt und Erlösung, sie beschreiben vor allem die bei der Verehrung der Gottheiten vorzunehmenden Riten, sie machen weiterhin eingehende Angaben über die Ausführung von Meditationsübungen, sie nennen die heiligen Formeln, Sprüche und Hymnen, die zur Verwendung gelangen sollen und erläutern ihre Angaben bisweilen durch mancherlei Legenden" ${ }^{2}$ ).

Men doet evenwel goed in dit, nog slechts hier en daar op 'n zeer beperkt gedeelte verkende, oerwoud van sectarisch-godsdienstige literatuur enkele onderscheidingen aan te nemen. In de eerste plaats vinden we Viṣnuitische geschriften, meestal Saṃhitā's genaamd. Er zijn volgens de traditie 108 van deze Vaiṣnava- of PāñcarātraSamhitā's ${ }^{3}$ ), maar in werkelijkheid zijn er ongeveer tweemaal zooveel. Voor de Xe eeuw zijn ze niet aan te wijzen (dan in Kashmir), een eeuw later vindt men ze in het Tamil-sprekende Zuiden. Hun groote gelijkenis en parallellisme in velerlei opzicht met de beide hierna te noemen groepen maken het waarschijnlijk, dat er reeds dergelijke Saṃhitā's eenige eeuwen eerder bestaan hebben. In deze geschriften worden de godsdienstige opvattingen, leeringen en praktijken der Viṣnuitische secten geleerd. Echter blijkt er ook uit een inwerking der leeringen van het Çāktisme ${ }^{4}$ ) in het Viṣnuisme.

Het is voor ons doel niet noodig, bij deze groep lang stil te staan; we gaan daarom over tot de Çivaitische geschriften, de Ägama's in den engeren zin $^{5}$ ), waarvan er volgens de traditie $28^{6}$ ) zijn, ieder voorzien van eenige Upāgama's; het totale aantal van deze geschriften, eveneens zeer slecht bekend, bedraagt meer dan 200. Hiervan is het bestaan reeds eerder an te toonen: in de IXe eeuw, hoogstwaarschijnlijk is ook deze literatuur-soort ouder, volgens

1) Het woord wordt genoemd op pp. 389, 391 van onzen tekst.

2) H. v. Glasenapp, Die Literaturen Indiens, Walzel's Hdb. d. Lit. wiss., p. 114.

3) F. O. Schrader, o.c. Vg1. ook J. N. Farquhar, An outline of the religious literature of India, Oxford, 1920, pp. 182 vlgg.

4) $\mathrm{Zie}$ beneden.

5) H. W. Schomerus, Der Çaiva-Siddhānta, eine Mystik Indiens, Leipzig, 1912, Einleitung, pp. 7 vlgg.; Farquhar, o.c., pp. 190 vlgg.

6) Genoemd bij Schomerus, p. 14; Farquhar, p. 193. 
Schomerus zelfs veel ouder ${ }^{1}$ ). Zij leeren de opvattingen, leeringen en praktijken van de Çivaitische secten.

Zoowel de Visnuitische als de Çivaitische teksten kennen, althans in theorie, een indeeling in vier deelen, kāṇ̣a of pāda geheeten: jñāna-pāda, handelende over philosophische theologie, inleidend tot de kennis Gods; yoga-pāda, over geestesconcentratie, yoga-praktijk; kriyā-pāda, over het botiwen van tempels, het maken, oprichten en wijden van beelden; caryā-pāda, over godsdienstige vereering en de methode daarvan ${ }^{2}$ ). In werkelijkheid vindt men deze indeeling zelden gehandhaafd. De beide laatste afdeelingen worden bij voorkeur behandeld.

Hiernaast, parallel, nauw verwant en beinvloedend, staan de geschriften van het Çāktisme, in engeren zin des woords wel Tantra's genaamd. Van deze categorie ${ }^{3}$ ) heeten er 64 te zijn; er zijn echter verscheiden gespecificeerde opgaven, die onderling zoo uiteengaan, dat het totale aantal in de honderden loopt; vele hiervan zijn echter, naar alle waarschijnlijkheid, verloren. Van eenige geschriften van deze categorie valt het bestaan in de VIIe eeuw òf aan te toonen òf aannemelijk te maken; het is dus zeer wel mogelijk, dat ze nog eenige eeuwen ouder zijn. Ook hier zou men de genoemd vierdeeling van de stof kunnen onderkennen; het grootste gedeelte valt echter toe aan de bespreking der religieuze praktijk. In vorm zijn deze teksten dialogen van Çiva en Devi ${ }^{*}$ ); de god openbaart daarin de leeringen en observanties die z'n volgelingen moeten kennen en in acht nemen.

1) Schomerus, p. 10: Ve eeuw, ja nog vroeger.

2) Schomerus, p. 15. Vg1. ook Govindācārya Svāmin, in J. R. A. S., 1911, pp. 951 vlg.

3) Vgl. H. H. Wilson, Works, ed. R. Rost, I, pp. 240 vlgg. (oud, doch nog te gebruiken); M. Winternitz, Die Tantras und die Religion der Çāktas, Ostasiatische Zeitschrift, IV, pp. 150-163; A. S. Geden, in Encycl. of Relig. and Ethics, s.v. Tantras. - Uitvoeriger in de publicaties van A. Avalon, vooraI Principles of Tantra, 2 dln., London, 1914 en 1916; Introduction to the Mahanirvāṇa Tantra, 1e uitgave, Londen 1913 (vgl. in de 2e uitgave, The Great Liberation, Madras, 1927, p. X) ; van den zelfden auteur, niet onder pseudonym: Sir John Woodroffe, Shakti and Shākta, Essays and ađdresses on the Shākta Tantrashāstra, 3e uitg., Madras en Londen, 1929, dat een populaire uiteenzetting wil geven (wijdloopig, vaak meer propagandistisch-apologetisch dan beschrijvend). Voorts, kort, Bhandarkar, Vaiṣnavism, Çaivism etc. (Grundriss d. Indo-Arischen Phil. - III, 6), § 110 e.a. Vgl. ook Farquhar, o.c., pp. 199 vlgg., e.a.

$\left.{ }^{4}\right)$ Onder wisselende namen; zoo heet Çiva in het Mahānirv. T. Sadāçiva, in het Kulārṇava T. İçvara, elders Aghora, Sadyojāta, enz. 
$\mathrm{Nu}$ worden door de Hindoes zelf de termen samlitāa, ägama, en tantra volstrekt niet als onderscheiden aanduidingen voor resp. uitsluitend Visnuïtische, Çivaitische en Çāktistische literatuur gebezigd. Het ware wellicht wenschelijk om deze onderscheiding wel te maken ten einde verwarring en misverstand tegen te gaan; de feiten hebben we intusschen te accepteeren ${ }^{1}$ ). Nadere toelichting is echter wenschelijk, wanneer wij deze benamingen gaan bezigen, waar wij zelf spreken of schrijven over deze geschriften en de daarin behandelde leeringen en praktijken. Het ware, bij voorbeeld, toe te juichen geweest, wanneer Dr. Pigeaud, die in zijn ,Tantu Panggĕlaran” herhaaldelijk de termen „Tantrisme” en ,tantrisch” bezigt, zij het in 't kort, had uiteengezet, wat hij onder deze uitdrukkingen verstaat. Ik maak deze opmerking - met alle waardeering voor zijn belangrijke onderzoekingen - , speciaal naar aanleiding van wat hij ${ }^{2}$ ) over het Agastyaparwa zegt; onder meer, dat ,'t zeer belangwekkend (zou) zijn, indien 'n Skṛt werk aangewezen kon worden, waarop 't Angastyaparwwa berust..., omdat dit er toe zou kunnen bijdragen de herkomst der tantristische opvattingen op Java duidelijker te maken".

Hieruit zou men misschien concludeeren, dat onze tekst een tantristisch (Çāktistisch) geschrift is, wat, gezien bovendien de verwarde en vaak scheeve meeningen, die over ,het Tantrisme” bestaan, er sommige lezers toe zou brengen, den inhoud van het Agastyaparwa in een onjuist licht te zien.

Het zij mij daarom vergund hieronder even, zeer in het kort, een vergelijking te maken tusschen de beschouwingen van onzen tekst en leeringen en opvattingen van die Voor-Indische ,secten”, die men wel aanduidt met de benaming ,Tantrisme”. We kunnen ons daarbij tot eenige hoofdzaken beperken.

Thans moet ik iets zeggen over de genealogieën, speciaal over Dakșa's nakroost. Pigeaud ${ }^{3}$ ) doet de uitgebreide behandeling van de genealogie der rṣi's, vooral die van Dakṣa's dochters denken aan het Brahmāṇ̣a-Purāṇa. Dit kan men toegeven, in zooverre dat ook daar sprake is van dezelffle personen en hun familie. Doch dit alleen zegt zeer weinig: in zeer vele epische en vooral puranische teksten

1) Over deze terminologie bv. Schrader, o.c., pp. 13; 22; Woodroffe, Shakti and Shākta, pp. 51; 55. Vergelijk voor het gebruik bv. de volgende plaatsen uit het Mahānirvāṇa T.: 3,$123 ; 4,86 ; 4,101 ; 5,3 ; 5,17 ; 6,164 ; 8,9 ; 8,80$.

2) De Tantu Panggĕlaran, p. 325.

3) De Tantu Panggělaran, p. 325. 
vindt men melding gemaakt van deze genealogieën. Het feit alleen, dat in beide teksten van Dakșa c.s. sprake is bewijst volstrekt niet, dat zij op Java in een bijzondere, nauwe, relatie moeten hebben gestaan.

Bij nader toezien zal men merkwaardige verschillen ontdekken. In het Oud-Jav. Bmḍ. Pur. wordt, al is de tekst in bijzonderheden wel eens minder duidelijk ${ }^{1}$ ), geleerd, dat Dakșa bij z'n gemalin Prasūti 24 dochters had, van wie 13 aan Dharma, de 11 overige aan 11 verschillende echtgenooten tot vrouw werden gegeven. In het Agastyaparwa echter vinden we een geheel andere voorstelling. Dakșa heeft daar bij Prasūti 51 dochters $^{2}$ ), waarvan er 13 aan Prajāpati worden uitgehuwelijkt; 12 andere worden vrouwen van Dakșa's broers ${ }^{3}$ ). Zonder dat over de nog overgeblevenen iets wordt gezegd, leert de tekst, dat Dakṣa nog een vrouw nam, Asiktiki, dochter van Wirrana, bij wie hij 10 dochters kreeg, die huwden met Dharma; bij dezelfde echtgenoote verwekte hij nog 27 andere meisjes, die met de Maan trouwden ${ }^{4}$ ). Dat wordt dus 37 dochters uit 't tweede huwelijk. Bovendien lezen we verderop in het werk, dat Dakṣa er nog 13 had, die Kaçyapa tot vrouw gegeven werden ${ }^{5}$ ). Daar de moeder van deze meisjes niet genoemd wordt, zouden we kunnen aannemen, dat zij tot de 51 dochters van Prasūti behooren; daarvan zouden er dan nog 13 (51-13-12-13) niet nader aangeduid zijn. Doch dit behoeft niet.

$\mathrm{Nu}$ mag men hierbij wel in het oog houden, dat de opvatting van het O.-Jav. Bmḍ. Pur. steun vindt in het onderdeel vamça van een aantal Voor-Indische purāna's, die van het Agastyaparwa, voor zoover ik weet, niet. Zonder op de merkwaardige figuur van Dakșa ${ }^{6}$ ) in te gaan of lang bij z'n uitgebreid nakroost volgens de verschillende teksten stil te staan, herinner ik er aan, dat de opgaven over de talrijkheid zijner dochters uiteen loopen: in de episch-puranische teksten vinden we de aantallen $16,24,44,50$ en 60 ; het meest 24 ,

1) Vgl. de aant. bij p. 58, 22 van de editie en Acta Orientalia, XI, p. 227.

2) Zie p. 345 .

3) Zie p. 346.

4) Zie p. 349.

5) Zie p. 362.

6) Vgl. Hillebrandt, Vedische Mythologie'2 (Breslau, 1929), II, p. 86; Macdonell, Vedic Mythology (Strassburg, 1897), p. 46; von Schroeder, Arische Religion, I, p. 390 vlgg., idem, Wiener Zeitschrift für die Kunde des Morgenlandes, 23, 3 vlgg.; J. Charpentier, Die Suparṇasage (Upsala, 1922), pp. 312; 390 vlgg.; Wilson-Hall, The Vishṇu Pur. II, p. 9 e.a., enz. Oriënteerend: J. Dowson, A classical Dictionary of Hindu Mythology etc., s.v. 
50 en 60 . De toewijzing der dochters aan de echtgenooten variëert eveneens. Om ons tot het meest karakteristieke te beperken: wanneer de opgave luidt: 50 dochters $^{1}$ ), is de uithuwelijking als regel: 10 aan Dharma, 13 aan Kaçyapa, 27 aan Soma; is ze $60^{2}$ ), dan evenzoo benevens 4, 2, 2, 2 aan andere echtgenooten; is ze $24^{3}$ ), dan 13 aan Dharma en 11 aan 11 verschillende mannen. Daar de gevallen 50 en 60 groote overeenkomst hebben en in wezen hetzelfde zijn, zijn er twee hoofd-opvattingen, n.1. die van 24 en die van $50-60$. Hierbij komt, dat de teksten, die het aantal dochters op 24 stellen, Prasūti, die het op 60 stellen, Asiknī als Dakșa's echtgenoote vermelden. Op bijzonderheden kan ik hier niet ingaan: het zal echter voldoende duidelijk zijn, dat er omtrent Dakșa's ,gezin” (in hoofdzaak) twee lezingen bestaan. Deze komen nu merkwaardigerwijs vaak beide in denzelfden tekst voor. De voorstelling is dan echter zoo, dat Dakșa in een eerste geboorte, onder het Svāyambhuva-manvantara, met Prasūti gehuwd was, in een tweede geboorte, in een ander, n.1. het Cākșuṣa-, manvantara met Asiknī.

In het Agastyaparwa heeft hij bij "Asiktiki” 10 dochters voor Dharma en 27 voor Soma. Nemen we aan dat de 13 voor Kaçyapa ook dochters van $\mathrm{A}$. waren, dan zijn deze 50 in overeenstemming met vele Voor-Indische teksten, niet alleen in aantal, maar ook - behoudens kleinigheden - in namen.

Hierbij heeft Dakṣa dan echter nog Prasūti en haar kinderen, en van een andere geboorte of een ander manvantara is geen sprake. En niet 24, maar 51 is het aantal. Maar de namen van de 13 vrouwen van Prajāpati stemmen, behoudens enkele afwijkingen, overeen met die van Dakșa's 13 dochters, die in de Voor-Indische teksten en in het O.-Jav. Bmḍ. Pur. met Dharma huwen. En ook de groep die met Dakșa's manlijke verwanten trouwt is in hoofdzaak dezelfde als het 11-tal en hun mannen in de bedoelde werken. Vreemd blijft het getal 51. Meer nog dan de Indische teksten met de dubbele voorstelling van Dakṣa's nakroost maakt onze tekst den indruk een samensmelting van twee tradities te geven. Zonder eenige poging te doen tot verklaring of motiveering geeft het Agastyaparwa beide

1) Matsya Pur. 4, 55; Mbh. 1, 2577 ; 3133 vlg.; 12, 7537 vlgg.; Manu 9, 129.

2) Brahma Pur. 3, 26 vlgg.; Linga Pur. 1, 63, 10 vlgg.; Matsya Pur. 5, 12 vlgg.; Hariv. 142 vlgg.; Bmụ. Pur. 2, 2, 31 vlgg.; Vā. 65, 158 vlgg., e.a. Vgl. ook Jahn, op Saura-Pur. adhy. 28.

3) Mārk. Pur. 50, 19 vlg.; Vi. Pur. 1, 7, 20; Linga Pur. 1, 70, 282 vlgg.; Bmọ. Pur. 1, 9, 47 vlgg.; Và. Pur. 10, 23 vlgg., e.a, 
vrouwen van Dakșa en haar kinderen terstond achter elkaar. Dit wijst er, naar mij waarschijnlijk voorkomt, op, dat de in het Agastyaparwa vertegenwoordigde tekst jonger is dan die teksten waarvan de auteur of compilator het onderscheid in manvantara, dus het bestaan van twee Dakșa's, aanbracht of handhaafde.

Welke zijn nu de Sanskrit teksten waarin Dakșa met tweeërlei gezin voorkomt? Het zijn van de 18 traditioneele Purāna's Padma, Viṣnu, Kūrma, Linga, Brahmānḍa en Vāyu. Dat de twee laatstgenoemde deze merkwaardigheid eveneens hebben, interesseert ons wegens de nog nader te bespreken mededeeling in den colophon van ons geschrift, waarin het zich in nauwe betrekking tot het Brahmāṇda-Purāṇa stelt ${ }^{1}$ ), waaraan het Vāyu-Purāṇa zeer na verwant is ${ }^{2}$ ). Bijzondere conclusies mogen we echter, daar verscheidene andere teksten dezelfde merkwaardigheid hebben, niet trekken. Ook het voorkomen van 50 dochters van Dakșa en „Asiktiki” in onzen tekst tegenover 50-60 elders leert niet veel. Immers uitdrukkelijk genoemd wordt het getal 50 niet. Merkwaardig is echter wel, dat een aantal Purāṇa's eerst melding maakt van 50 , zonder dit aantal te noemen, daarna, en wel niet veel verder in den tekst, het getal 60 noemt en ook de 10 meerdere specificeert ${ }^{3}$ ). Letten we nu op de plaatsen in de Brahmāṇ̣a-Vāyu-versie: Bmọ. 1, 37, 44; Vā. 63, 41 ; bij vergelijking met het Oud-Jav. Bmọ. Pur. blijkt, dat nog wèl het voorafgaande, niet meer dit hoofdstuk daarin vertegenwoordigd is ${ }^{4}$ ); evenmin is de tweede plaats (Bmḍ. 2, 2, 30; Vā. 65, 157) daarin opgenomen. Hieruit volgt, dat de auteur of bewerker van het Agastyaparwa niet afhankelijk is van het O.-Jav. Bmḍ. Pur. in den vorm waarin wij het kennen.

Er zijn echter nog eenige merkwaardige omstandigheden. Het Mahābhārata bevat ook en wel op meer dan één plaats opgaven over Dakṣa's dochters: in het Ie boek $^{5}$ ) worden er 50 vermeld, in het

1) Zie beneden, p. 379 .

2) Vgl. boven, p. 347 , 11. 4 .

3) Br. 2, 48; 3, 27 vlg.; Har. 103 vlg.; 143 vlgg.; Çivadharmaç. 53, 14 vlg.; 54, 14; Vi. 1, 15, 76 vlg.; 1, 15, 103; Mt. 4, 55; 5, 13 vlg.; Và. 63, 41 vlg. en Bmḍ. 1, 37, 44 vlg. hebben de overige 10 reeds op de eerste plaats, op de tweede (Và. 65, 157 vlg.; Bmḍ. 2, 2, 30 vlg.) het getal 60 en een korte herhaling, zonder getallen; hierin schijnt een latere hand te herkennen, die de eerste passage heeft aangevuld naar de tweede, en deze heeft omgewerkt. Zie ook Kirfel, P.P. 160, 29, 1 .

4) Zie Acta Orientalia, XI, p. 241.

5) Mbh. 1, 2577. Zie ook 1, 3133; 12, 7537. 
XIIe boek ${ }^{1}$ ) 60 . Opmerkelijk is nu, dat beide genoemde passage's uit het Ie boek in het Oud-Javaansche Addiparwa ontbreken ${ }^{2}$ ).

Nog merkwaardiger echter is het, dat op een andere plaats, vroeger in het $\bar{A}$ dipar wa, wel melding gemaakt wordt van een aantal dochters van Dakṣa. Vóór het bekende verhaal van Kadrū en Vinatā voegt de O.-Jav. tekst ${ }^{3}$ ), volstrekt niet misplaatst, een mededeeling in omtrent „Kaçyapa, den zoon van Marīci, kleinzoon van Brahmā; „deze kreeg van Dakșa 14 dochters”. Van 12 dezer dochters worden de kinderen even vermeld ${ }^{4}$ ), daarna volgt de geschiedenis van de twee resteerende, Kadrū en Vinatā. Nu heeft Van der Tuuk ${ }^{5}$ ) opgemerkt, dat het getal 14 bedorven moet zijn, en wel op grond van de opgaven in de hem ter beschikking staande Sanskrit teksten, het Mbh. en het Viṣnu-Purāṇa. Deze meening is evenwel voor bestrijding vatbaar. Weliswaar is het geijkte aandeel van Kaçyapa in Dakșa's dochters 13, doch er zijn afwijkingen, b.v. $8^{6}$ ) en $17^{7}$ ). Het getal 14 komt echter in Voor-Indië ook voor en wel in de Bmḍ.Vā.-versie ${ }^{8}$ ), in een deel, waar de tekst ,überaus stark erweitert und überarbeitet” blijkt te zijn ${ }^{9}$ ). Weliswaar stemt een deel der namen, die daar worden opgesomd niet overeen met die van het O.-J. A Adip., doch de overeenstemming in aantal, gevoegd bij de bijzondere plaats in den Ādiparwa-tekst waar van Kaçyapa's vrouwen sprake is wettigt het, dat we onze aandacht daarbij even bepalen. Als de laatst genoemde Bmḍ.-Vā.-passage nooit op Java bestaan heeft, is er dan in Voor-Indië verband geweest tusschen de daarin neergelegde opvatting, dat Kaçyapa 14 dochters van Dakșa kreeg en de overeenkomstige in de bedoelde passage in het Oud-Jav. A diparwa?

Telt men tenslotte de 10 dochters die met Dharma huwden ${ }^{10}$ ), met de 27 die vrouwen van de Maan werden ${ }^{11}$ ) op bij de 14 van Kaçyapa,

1) Mbh. 12, 6136.

2) Vgl. de ed., pp. 63 vlgg.; 72 vlg.

3) Àdip., ed. Juynboll, p. 29, r. 17 vlgg.; vgl. ook Hazeu, T. B. G. 44, pp. $310 \mathrm{vlg}$.

4) Tot p. 30 , r. 4 .

5) Kawi-Bal. Wdb., II, 438.

6) Rāmāyaṇa 3, 14, 11 .

7) Vgl. P. W. s.v. Dakșa.

8) Bmụ. Pur. 2, 3, 55; Vā. Pur. 66, 54.

9) Kirfel, Das Purāṇa Pañcalakṣaṇa, p. XXXIV. Kirfel ziet ook in de bewerking van dit deel de hand van een diaskeuast, die volgens hem tusschen \pm 335 en \pm 620 aan het werk geweest moet zijn. Verg. mijn opm., Acta Orientalia, XI, 239.

10) Vgl. Bmụ. Pur. 2, 3, 3; Vā. Pur. 66, 3.

11) Vgl. Bmọ. Pur. 2, 3, 53; Vã. Pur. 66, 53. 
dan komen we tot 51 , het vreemde aantal in het Agastyaparwa ${ }^{1}$ ). Echter heeft Dakṣa daar bij Prasūti 51 kinderen, die bovendien anders worden uitgehuwelijkt. Moeten we misschien toch, ondanks deze verschillen de bron voor het antal van 51 in ons geschrift in deze richting zoeken? Zou wellicht hier de conclusie kunnen luiden: het Agastyaparwa staat in een zekere relatie met de Bmḍ.-Vā.-versie van de Purāna-stof, althans met daarin voorkomende tekstdeelen; het vertoont er echter sporen van, dat het in een verder stadium van ontwikkeling verkeert?

Nauw samenhangend met de Dakșa-genealogie is de passage, waarin onze tekst de nakșatra's, de 27 vrouwen van de Maan, nader behandelt, een alleszins merkwaardig gedeelte. Nakṣatra's in de meer beperkten zin des woords zijn 27 of 28 sterren of sterregroepen, die in de nabijheid van de ecliptica liggen ${ }^{2}$ ); dat ze als dochters van Dakșa gelden, is een algemeen-puranische voorstelling. Behalve dat wordt in eenige Sanskrit teksten van hun aantal gewag gemaakt; voorts van de goden, waaronder ze ressorteeren; ergens ook van de ṛ̣i-families, waartoe ze behooren en in een paar teksten ook van hun gedaante.

De aantallen kan men vinden in den Nakṣatrakalpa (Atharvapariçișța I), 1, 1 vlgg., in Çrīpati’s Jyotișaratnamālā 6, 74 vlgg., en in de Çākalyasamhitā van den Brahmasiddhānta, de mededeelingen over hun gedaante in de beide laatstgenoemde teksten ${ }^{3}$ ). De Nakṣatrakalpa noemt de rși-families, die het O.-J. Agastyaparwa weglaat, evenals het de goden buiten beschouwing houdt. Er worden door Kirfel $^{4}$ ) twee Purāna-plaatsen ${ }^{5}$ ) geciteerd, die eveneens de namen der nakșatra's vermelden, doch er zijn er meer: voor ons merkwaardig is het, dat bijna terstond na de vermelding van de Muhūrta's, Bhānu's en van Ghoṣa in het Skt. Bmọ. Pur. ${ }^{6}$ ) en in het Vā. Pur. ${ }^{7}$ ) een passage volgt over muhürta's (de 30 deelen van den dag) en

1) Er valt nog op te merken, dat het Vā. Pur. (66, 78 a enz.) in een passage die niet in het Bmḍ. Pur. voorkomt, het nakroost opnoemt van de vier andere mannen, aan wie Dakșa nog 10 dochters gaf.

2) De aequivalenten: Kirfel, Die Kosmographie der Inder, p. 36. Zie aldaar pp. 34 vlgg., 138 vlgg., waar ook literatuur.

3) Bijzonderheden : Kirfel, o.c., p. 138.

4) T. a. p., n. 6 .

5) Garuḍa Pur. 59, 1 vlgg., Matsya Pur. 124, 54 vlgg. Anand. = 123, 54 vlgg. Jiv. Vidy. Vgl. over laatstgenoemde plaats in verband met het O.-J. Bmḑ. Pur. Acta Or. XI, pp. 257 vlg.

6) 2, 3, 34 vlgg.

7) 66,35 vlgg. 
wat zich daarbij aansluit, waarna een opsomming van de nakșatra's komt, gerangschikt volgens de groepen, waarin ze naar hun ligging als wegen, banen, van de zon en planeten worden ingedeeld. Deze in meer teksten staande opsomming volgens groepen pleegt te beginnen met Açvinī, zoo ook in onzen tekst; Nakṣatrakalpa c.s. beginnen met Kṛttikāh ; déze opsomming heeft er $27(3 \times 3 \times 3)$, de andere 28. We mogen dus, dunkt mij, concludeeren, dat het 27-tal nakșatra's in het Agastyaparwa naar alle waarschijnlijkheid stamt uit een beschrijving of opsomming volgens de planeten-banen, al is van die indeeling in $3 \times 3 \times 3$ geen sprake meer, en dat hier de Bmḷ.-Vã.-tekst meer nabij staat dan andere, waar deze passage kort wordt afgedaan ${ }^{1}$ ). De aantallen der sterren en de gedaanten der nakșatra's komen daar niet voor; over de merkwaardige afwijkingen van onzen tekst van de opgaven van bovengenoemde VoorIndische geschriften vergelijke men de aanteekeningen.

Het is evenwel de moeite waard de interessante opsomming van onzen tekst eveneens te vergelijken met opgaven van nakṣatra's en sterrebeelden, die we uit Bali en Java op astrologische kalenders en van elders kennen. Men vindt in een artikel van Dr. Alfred Maass, Sternkunde und Sterndeuterei im malaiischen Archipel ${ }^{2}$ ) een en ander verzameld. Het blijkt, dat de meening van Maass, dat alleen „Krittika” (Skt. Kṛttikāḥ) onder de „,von den Balinesen benutzten” sterren met de maanhuizen in verbinding staat, eenigszins gecorrigeerd kan worden. Er zijn nog een paar punten van overeenstemming, wanneer men n.1. niet alleen op de namen let, maar ook op de bijzonderheden die van de betreffende sterren of sterregroepen in de Voor-Indische bronnen worden meegedeeld. Deze overeenstemmingen zijn echter zeer gering in aantal.

Meer overeenkomst bestaat er tusschen de andere Javaansche en Balineesche opgaven en onzen tekst; doch ook hier zijn vele verschillen. Het treft ons, dat terwijl in het Agastyaparwa zoowel de Sanskrit namen van de nakșatra's alsook de Javaansche namen genoemd worden, de iclentificatie van de met de laatste benaming aangeduide sterren, voorzoover mogelijk, met die van de nakșatra's slechts in één geval, en dan nog wel gedeeltelijk, blijkt overeen te stemmen. Hoe dit te verklaren?

1) Vgl. Kirfel, Das Purāṇa Pañcalakșaṇa, 161, 34; ook 212, 21 anders. Plaatsgebrek verhindert mij de groepeering der nakșatra's toe te lichten; men zie bv. Wilson-Hall, Vishṇu Pur. II, pp. 264 vlg., n.; Thibaut, Astronomie, u. s. w., pp. 12 vlg.; 23 vlgg.

2) T. B. G. 64 (1924), pp. 163 vlgg.; zie de Aanteekeningen. 
Van Hinloopen Labberton ${ }^{1}$ ) meende op grond van een door hem gepubliceerde Balineesche nakșatra-lijst, dat de opgaven daarvan afgezien van Krĕtika - geheel afwijken van de Voor-Indische nakșatra-lijsten. Ook van het sterrebeeld Kṛttikāh bestaat echter, betoogt hij, een inheemsche naam in den Archipel, wuluh op Java e.a. Hieruit volgt, zoo is zijn redeneering, dat deze sterregroep in Indonesië van ouds bekend geweest is, zoodat men mag aannemen, dat de Javanen zelf in latere tijden Hindoesche namen hebben overgenomen en ook ,geläufig" geworden Sanskrit woorden op hun eigen sterrebeelden hebben toegepast. Immers, men vindt enkele Sanskrit woorden (,gajah, dupa” e.a.) onder de benamingen van deze sterrebeelden.

Maass zelf is de meening toegedaan, dat de 28 sterren van de door Van Hinloopen Labberton gepubliceerde lijst ,nur ein Bruchstück eines astrologischen Kalenders, palalintangan, bilden, da sie in keiner Weise, ... irgend welche Beziehungen zu den Mondstationen der alten Inder haben” (met event. uitzondering van „kritika”). Hij vergelijkt eenige astrologische kalenders die steeds 35 sterrebeelden geven en vindt daaronder de 28 nakșatra's niet. Z'n conclusie luidt : „Soweit wie unsere heutigen Kenntnisse über die Astronomie der Balinesen reichen, sind die 28 Mondstationen der alten Indier noch nicht bei ihnen in irgend einer annäherenden Form gefunden worden". In het Agastyaparwa staan ze echter vermeld, evenwel in een passage die zoo goed als zeker is op te vatten als een van commentaar, van verklaring, voorziene bewerking van een Sanskrit tekst. De Sanskrit benamingen zijn dus overgenomen in dit Oud-Javaansche geschrift, en daarna wordt den lezer duidelijk gemaakt, welke sterren met die benamingen worden aangeduid. „Is er een sterrebeeld van den vorm van een wagen, dan is dat (de dusgenaamde) Rohinī”, enz. Mogelijk is hierbij, dat, evenals in andere bovengenoemde Sanskrit teksten melding wordt gemaakt van bijzonderheden omtrent den vorm van de nakșatra's ook de Vorlage van onzen Oud-Javaanschen Agastyaparwa-bewerker deze bevatte; ook de aantallen der sterren worden opgegeven. Bij no. 4 der reeks is de formuleering echter anders, ,w wat echter betreft het sterrebeeld, dat kop van het zwijn Damalun genoemd wordt, volgens zeggen der menschen, dat heet Pusya". Hier wordt dus met een naam die .,men”, die ., het volk" aan een ster geeft een der nakșatra's geïlentificeerd. Heeft het er niet allen schijn

1) In zijn Geillustreerd Handboek van Insulinde, Amsterdam 1910, geciteerd bij Maass, o.c., p. 165. 
van, dat deze ,tandas nin wuk damalun” een op Java bekende verschijning aan het firmament was, de drie eerder genoemde niet, dat deze a.h.w. eerst gezocht moesten worden met behulp van de omschrijving die de Sanskrit tekst gaf : ,ziet ge een sterrebeeld als..., welnu, dat is ..."?

$\mathrm{Nu}$ wordt in 7 van de 26 gevallen (de lijst is incompleet; zie de Aanteekeningen) begonnen met ,yen hana"; twee maal luidt het begin van een nieuwe opgave ,llana ta wintan: er is een ster" (de eerste maal lacuneus). Ook hierin kunnen we de mededeeling van een den lezer niet bekend feit, het in kennis brengen met een hem onbekend sterrebeeld zien. Achtmaal wordt de opgave geformuleerd als bij no. 4, met „lii nii loka”. De 8 sterrebeelden heeten: tandas nin wuk Damalun, lañcan si wadwan, kĕbwan sandan, wañun²an salahukur, tangunan hru, kadi hĕḍuk tinimbun, sankal tikĕl, puyuh atarun. Eenige malen wordt sinanguh gebezigd, eenige malen niet, een kerr staat kadi voor de benaming. M.i. mogen we in dit achttal sterrebrelden zien die de Javanen op 't tijdstip van de bewerking van deze passage kenden; merkwaardigerwijze kunnen we aan de manier, waarop de tekst zich uitdrukt zien hoe deze benamingen gegeven zijn naar het uiterlijk, naar den vorm van zoo'n sterrebeeld. „Wat het gesternte betreft, dat volgens het zeggen der menschen is als „hĕḍuk tinimbun"; -- ,het sterrebeeld, dat naar 't zeggen der menschen voor - gehouden wordt, - genoemd wordt"; ,het sterrebeeld „puyuh atarun”, zooals men zegt”. Van deze 8 zijn er 4 met zekerheid in de opgaven bij Maass terug te vinden.

Bij de overige 9 is de formuleering weer anders, nòch yen..., nòch lin nin loka worden gebezigd. Als de zin gaaf is overgeleverd, wordt bij Citrā en Svāti (in één adem genoemd) slechts de naam en het aantal der sterren meegedeeld; hierin is niet meer te zien dan de bloote weergave van den Sanskrit tekst. Evenzoo bij Anurādhā. Bij Pūrvāṣāçhā en Çatabhișa(j) krijgen we den indruk, dat de auteur bij den lezer de bekendheid met een bepaalde figuur aan den hemel veronderstelt: kunain ikain wintain pasagi akusu, ycka P. naranya; kunaì ikain kadi k. rüpanya, ycka Ç. íaranya. Bij Pūrwa- en Uttarabhādrawad̄ krijg ik dezen indruk niet; bij de twee resteerende weer wel.

Het is mogelijk, dat de hier gegeven interpretatie te subjectief is. Dat de verschillen in formuleering van de opgaven der nakșatra's in de in onzen tekst gegreven lijst uitsluitend een gevolg zijn van een - overigens in dergelijke geschriften niet bijster geapprecieerd - 
streven naar afwisseling, lijkt me zeer onaannemelijk. Is de voorgedragen opvatting in hoofdzaak juist, dan mag men, dunkt mij, concludeeren, dat op het oude Java ten tijde van de bewerking van dezen tekst een aantal sterrebeelden bekend waren, en dat volgens den auteur eenige daarvan (het zou wel zeer onwaarschijnlijk zijn, dat de genoemde alle den Javanen bekende sterrebeelden zouden zijn) gelijk te stellen zijn met een aantal nakșatra's. Op te merken valt daarbij, dat - zooals reeds boven gezegd - behalve in één geval en dan nog slechts gedeeltelijk, de identificaties bij Maass, o.c. te vinden niet overeenstemmen met de objecten aan het firmament, die met de nakșatra's bedoeld zijn. Hoe het hiermee staat, blijft nog nader te onderzoeken. Men houde daarbij tevens in het oog, dat niet alleen in den Archipel (Java-Bali), maar ook in Voor-Indië verschillende opgaven voorkomen: een afbeelding uit „An illustrated Ardha Magdhi Dictionary" (Bombay) wijkt in een aantal punten af van de bij Kirfel, Kosmographie der Inder, gegeven voorstelling.

Dan kunnen we nu de verschillende episoden zeer beknopt de revue laten passeeren, althans wat de hoofdzaken betreft ${ }^{1}$ ).

Over de schepping zal ik kort zijn: we herkennen er de kosmogonische leeringen van de Sāmkhya-philosophie in, zooals ze in de purāna's zijn bewerkt ${ }^{2}$ ); het uitgesproken Çivaitisch karakter van onzen tekst blijkt echter duidelijk uit de omstandigheid, dat het Çiva is en wel in z'n aspect Sadāçiva ${ }^{3}$ ), die de schepping aan den gang maakt. Is het kosmisch Ei eenmaal ontstaan, dan zet Brahmā de schepping voort $\left.{ }^{4}\right)$; men vergelijke de aanteekeningen.

De inhoud van de zesde paragraaf, de beantwoording van Dṛhhasyu's vraag, hoe 't komt, dat men naar hemel of hel gaat, is ons (van kleinigheden afgezien) uit Voor-Indische teksten overbekend. 's Menschen daden in zijn aardsch bestaan zijn beslissend of hij na zijn dood den hemel zal bereiken of wel Yama's rijk zal vervallen; in het laatste geval hangt het van den aard zijner zonden af, in welke der vele helleruimten, en voor hoe lang, hij zal moeten worden gepijnigd, waarin zijn folteringen zullen bestaan en hoe hij dan 'n nieuwe geboorte zal bereiken. Met eindelooze variatie en tot in bijzonderheden afdalende onderscheidingen worden ons de verschillende soorten van zonden en overtredingen, de hellestraffen en de

1) Een aantal bijzonderheden wordt in de aanteekeningen besproken; over Pigeaud's Nakșatrarūpa (T. B. G. 65) aan het einde van deze inleiding.

2) Vgl. O.-J. Bmḍ. Pur. p. 55, 12 vlgg., met de aanteekeningen.

3) Zie de aant.

4) Vgl. ook andere Çivaitische teksten, bv. Saura Pur., adhy. 21. 
wedergeboorten in allerlei producten der schepping geschilderd. Ook de karakter- en lichamelijke eigenschappen en eigenaardigheden van den mensch komen hierbij ter sprake: lichaamsgebreken, ziekten, kwalen zijn een gevolg van zonden, begaan in een vorige existentie ${ }^{1}$ ). De zoogenaamde „Wetboeken”, Dharmaçāstra's, de Purāna's en smrti-puranische deelen uit het epos bevatten vele passage's aan deze en na-verwante onderwerpen gewijd. Veel hebben deze beschrijvingen, in het algemeen gesproken, gemeen; in uitvoerigheid, volgorde, detailkwesties is er echter nogal variatie. Over de eigenschappen van zondaren in dit en 'n volgend leven handelt b.v. Manu, 11, 48 vlgg.; een opgave omtrent de zoeningen die men moet verrichten om deze zonden te delgen, sluit hier terstond bij aan; de zonden worden geclassificeerd; elders worden de toekomstige existenties in geval van zonde en overtreding geleerd $\left(12,53\right.$ vlgg.) $\left.{ }^{2}\right)$. Specificatie van misdaden en wedergeboorte in gradatie leert ons b.v. het Brahma Purāna, 217, 31 vlgg. kennen. Vreeselijke hellestraffen worden herhaaldelijk beschreven ${ }^{3}$ ); bekend is b.v. het Mārkaṇdeya Purāṇa, hoofdstuk 14, waar 91 vlgg. ons in verband met het Agastyaparwa treffen: ,... een brahmanenmoordenaar,..., hij, die het bed van zijn leeraar schendt, wordt vele duizenden jaren aan alle kanten gezengd, daarna wordt hij weer geboren behept met melaatschheid, tering enz."; karaktereigenschappen van zondaren die in de hel geboet hebben komen later ter sprake (zie 15, 39-42). Doch niet alleen dharmaçāstra's, purāṇa's en het epos, ook een tekst als de Ahirbudhnya Samhitā staat op dit standpunt: „The diseases, therefore, are nothing but the sprouting forth of the sins we have committed in former lives" ${ }^{4}$ ), ook de Tantra's leeren, dat zonden leiden tot pijn, smart en ziekte ${ }^{5}$ ). In de aanteekeningen hoop ik op enkele bijzonderheden te kunnen wijzen.

De inhoud van $\S 7$ is gevarieerd, en voor een deel eveneens uit verschillende Voor-Indische teksten bekend. De tocht naar den hemel van de ziel, de hellepijnigingen, de beschrijving van askese, offer en goede werken (vrome stichtingen), die van de vijf mahāyajña's, dit alles is zonder den minsten twijfel uit Voor-Indische bron. Voor

1) Behalve de hierna te noemen plaatsen, bv. Mbh. 3, 208, 14.

2) Zie ook Vișnu Smṛti, a. 44 en 45; Yãjñavalkya, 3, 134 vlgg.; 207 vlgg.

3) Vg1. ook Varāha Pur. a. 203; 204, e.a., zeer uitvoerige beschrijving! Weer anders Padma Pur. 4, 48, 40 vlgg. Kort: Agni Pur. 370, 30 vlgg. Zeer interessant ook E. Abegg, Der Pretakalpa des Garuḍa-Purāṇa, pp. 82 vlgg.

4) Zie Schrader, Pāñcarātra, p. 129.

5) Vg1. bv. Mahānirvāṇa Tantra, 11, 14. 
het volgende gedeelte, de incarnaties van menschen, die hun deugden en verdiensten en van lieden, die ook hun gebreken hadden, staan mij nu geen parallel-plaatsen ter beschikking ${ }^{1}$ ). De sfeer en de citaten die ook hier voorkomen pleiten sterk tegen het vermoeden van Javaansche interpolatie. Hoe het zij, bij alle overeenkomst, die dergelijke tractaatjes in de Sanskrit literatuur hebben, is er toch ook steeds variatie, meerdere of mindere uitvoerigheid. Niet alleen bekende leeringen, ook nieuws aan te treffen in dit Javaansche geschrift zal ons welkom mogen zijn!

Over den inhoud van de hierop volgende paragrafen moet ik kort zijn, daar mij voldoende vergelijkingsmateriaal ontbreekt. Het nakroost van Kaçyapa's vrouwen wordt hier beschouwd in verband met haar aard en karakter; over de karakters zelve wordt uitgeweid en een aantal zeer interessante digressies gemaakt. Zeer merkwaardig is de passage over Uḍug Basur, waarin ook de naam van Java genoemd wordt; een aantal m.i. te vergelijken gegevens vindt men in de aanteekeningen; evenwel meen ik op grond daarvan nog geen hypothese ontrent den aard van Uḍg Basur te mogen opstellen. Van veel belang is ook de vermelding van het brahmahatyā-avontuur van Indra en wat zich daarbij ansluit.

Op de interessante beschouwingen van de $\S \S 13$ en 14 ga ik niet nader in; het lijkt mij beter, dat de gegevens van onzen tekst met die uit andere bronnen in een afzonderlijke verhandeling worden verwerkt. Wat de voornaamste strekking en de algemeene lijn betreft stemmen methoden en einddoel bij den yoga van verschillende richtingen in den grond van de zaak overeen. Beschouwingen, langer of korter, vindt men behalve in de meer opzettelijk aan het onderwerp gewijde geschriften in vele purāṇa's - zie b.v. Vãyu Pur. a. 11 vlgg.; Agni Pur. a. 372 vlgg.; Saura Pur. a. 12 vlg.; Viṣnu Pur. 6, a. 7 (Wilson-Hall, V, pp. 226 vlgg.; ook elders treft men ze aan, zie b.v. het los van den context staande stuk bij Manu, 2, 88-100).

In de volgende paragrafen treft het ons, dat de beschreven familieverhoudingen overeenstemmen met de lezing van den Brahmāṇ̣aVãyu-tekst. Speciaal het nakroost van Kaçyapa en Tāmrā is merkwaardig: ze hebben volgens onzen tekst vijf dochters, waarvan er één met Aruṇa, vier met Garuḍa huwen. Elders (Brahma Pur. 3, 92; Hariv. 221; Viṣnu Pur. 1, 21, 14; Bmụ. Pur. 2, 7, 445; Vā. Pur.

1) Men denke evenwel aan een tekst als bv. de door Lévi, Versl. VIe Congr. Oost. Gen. in Ned., 1929, p. 7 vlg., besprokene. [Zie addenda]. 
69, 316; Linga Pur. 63, 29 e.a.) hebben Kaçyapa en Tāmrā zes dochters; zoowel het telwoord als de namen worden meegedeeld. Eén tekst drukt zich echter anders uit, het Vãyu Pur. Dit geeft: bahvanyās to abhivikhyātās, Tāmrāyā̧⿻ ca vijajñire| Çyeñ Bhāsì tathā Krauñà Dhṛtarāșțī Çukì tathā. De zesde, Gṛdhrī of Gṛdhrikā, ontbreekt in dezen tekst. Men merke voorts op, dat de andere teksten de zes namen in één versregel geven, b.v. Krauñcī (deze naam wel eens anders) Çyeñ ca Bhāsì ca Sugrī̃ū Çucir Gṛdhrikā (Br. Pur. 3, 93). Behalve natuurlijk het Vãyu Purāṇa wijkt hier het Bmḍ. Pur., volgens het door Kirfel gebruikte handschrift te Bonn ${ }^{1}$ ) af, waar

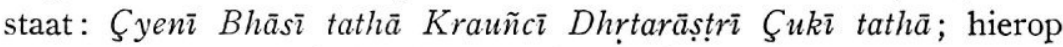
volgt Arunasya ca Grụdhrī ${ }^{2}$ ) tu... Sampātin ca Jațāyum ca prasūtā pakșisattamau. De gedrukte Bmḍ. Pur.-tekst heeft: Gṛdhrì Bhāsì Çukī Krauñci Çyeñ ca Dhṛtarāștrikā. Het vermoeden ligt dus voor de hand dat de tekst, waarop het Oud-Javaansche Agastyaparwa hier teruggaat, nauwer verwant is met de Vāyu-Brahmāṇ̣a-versie dan met de andere Purāna's, temeer daar ook de huwelijksbanden die tusschen Aruña en Çyenī en tusschen Garuḍa en de vier andere dochters in het Agastyaparwa bestaan in het Vāyu Pur. worden weergevonden. Op een aantal bijzonderheden maak ik in de aanteekeningen nog attent. Hier zij er echter op gewezen, dat de merkwaardige moraliseerende passage die onze tekst aan de vermelding van de geschiedenis van Jațāyu aanknoopt in de genoemde parallelteksten niet voorkomt.

In $\S 18$ valt de aandacht te vestigen op de passage, waar de muktapada wordt beschreven; daarbij. wordt de terminologie van verschillende godsdienstige richtingen naast elkaar gebezigd. In de Sang hyang Kamahāyānikan is, zooals men in de aanteekeningen kan vinden, een parallel.

In $\S 20$ volgt een zeer interessante passage over den geestelijken leeraar en de initiatie. Reeds veel oudere geschriften kennen de geëerde positie van den ācārya, den guru. Om mij te beperken : over den term dit: een guru is oorspronkelijk in het algemeen een persoon van aanzien, een persoon wien men eerbied schuldig is, superieur, b.v. ouders, oudere verwanten, leeraar; het woord gaat echter bij voorkeur gebruikt worden voor den geestelijken leeraar. Zoo wordt het door Manu 2, 142 voor den vader gebezigd (hij die de conceptierite enz. vervult en het kind voedt); de brahmaan die een leerling

1) Ms. S. 119 Univ. bibl. Bonn, vgl. Kirfel, P. P., 208, 3 en p. VII.

2) Vgl. Kirfel, P. P. 208, 4. 
initieert en hem den Veda met den Kalpa (d.i. de sūtra's die betrekking hebben op offers) en de Rahasyas (d.i. de Geheimleeren, Upanisaden enz.) onderwijst heet daar $(2,140)$ ācārya; upādhyāya is de man die voor loon in een deel van den Veda of ook in een van de Anga's van den Veda (additioneele wetenschappen) onderricht geeft $(2,141)$; in 2, 149 wordt echter hij die iemand in den Veda onderwijst ook z'n guru genoemd. Een guru moet men, onder omstandigheden, met van ander verkregen gaven onderhouden $(4,251$; Vās. 14, 13 e.a., vgl. het Paușya-verhaal in Mbh. I). Men moet hem vereeren (2, 231 vlgg.); door z'n guru eerbied te betoonen en te dienen verwerft men de wereld van Brahman; hooger dan vader en moeder is hij in dit opzicht: iman lokam mātrbhaktya pitṛhakty $\bar{a}$. tu madhyamam | guruçuçūșayā to evam brahmalokạn samaçnute (2, 233; vgl. Viṣnu 31, 10; Mbh. 12, 108, 8 vlg.). Hij is de belichaming, manifestatie van Brahman, zooals de vader die van Prajāpati, de moeder die van de Aarde is (ācāryo brahmano mürtih etc., 2, 226); hij is heer over de wereld van Brahman, gelijk b.v. de priesters over die der goden (ācāryo brahmalokeçah̆, 4, 182; vgl. Mbh. $12,243,18=8870)$. Men krenke hem nooit $(4,162)$, enz. enz.

Zooals men ziet ging reeds oudtijds de vereering van den geestelijken leeraar zeer ver, doch deze hield op met het beëindigen van de ondergeschikte positie van den ,leerling”. Mettertijd werd dit echter anders. De guru, eerst een geestelijk leidsman, een herder van hen die zich aan zijn zorgen toevertrouwden, werd meer en meer een verheven en vereerenswaardig persoon. Bij allerlei secten werd deze leider, die leeken initieerde en theologisch en philosophisch onderricht gaf, beschouwd als te zijn in het bezit van transcendentale kennis en tenslotte gehouden voor 'n godheid op aarde, voor een onvoorwaardelijk te gehoorzamen en als een godheid te vereeren wezen van hoogere orde. Onbeperkte macht kreeg hij over z'n volgelingen, de belichaming op aarde van de hoogste godheid werd $\mathrm{hij}^{1}$ ). Berispingen, vermaningen, ja verstooting, aan den anderen kant ook absolutie ${ }^{2}$ ) kwamen in zijn handen. Gold bij Manu

1) Vgl. bv. H. H. Wilson, Essays and Lectures chiefly on the Religion of the Hindus, Works I, dl. I A sketch of the religious sects of the Hindus, vgl. p. 379; W. Crooke, in E. R. E., s.v. Hinduism; A. Avalon's publicaties, passim; Barth, Les religions de l'Inde, Oeuvres, I, pp. 199 vlgg.; W. J. Wilkins, Modern Hinduism, p. 28 vlgg.; Dubois-Beauchamp, Hindu Manners², pp. 124 vlgg.; Glasenapp, Hinduismus, pp. 76 vlgg.; Farquhar, Mod. rel. mov.; Konow, Hinduismen, p. 157, e.a.

2) Zie bv. Saura Pur. 52, 51.

D1. 92. 
$(12,83)$ naast Vedastudie, askese, het verwerven van inzicht, het bedwingen der zinnen en organen en ahimșā (het zich onthouden van krenken, onrecht en kwaad doen) de gurusevā, het dienen van den leeraar, als nihçreyasakaram param, als beste middel tot erlangen van heil, van de verlossing, later werd een blindelings volgen van de absolute autoriteit en onbeperkte macht van den leidsman vereischte. Bij sommige secten is het er zelfs van gekomen, dat de geloovigen zich zelf en hun bezittingen ter beschikking van den guru dienden te stellen.

Dat de guru belichaming van Brahman is, leerde reeds Manu ${ }^{1}$ ). Vele malen vinden we dezelfde leer bij lateren: een beeld in menschelijken vorm van het Hoogste Brahman is hij ${ }^{2}$ ), de belichaming op aarde van het Hoogste Brahman ${ }^{3}$ ), Guru en Godheid zijn identiek: ācāryam māṇ vijānūyān nāvamanyeta karhicit | na martyabuddhyāsüyeta sarvadevamayo guruh ${ }^{4}$ ); hij is de godheid zelve, zijn autoriteit is nog grooter dan die van de godheid, zijn gunst moet men nog eerder zien te verwerven dan die van Kṛșna, prathamam tu guruh püjyas tatạ̧ caiva mamärcanam (eerst moet de guru vereerd worden, daarna ik); gurau tuṣte harir tușthah (wanneer de guru voldaan is, is Hari = Viṣnu voldaan); harau ruște gurus trăta gurau ruște na kaçcanah (wanneer Hari vertoornd is, is de guru onze beschermer, wanneer deze toornig is, hebben we geen beschermer) ${ }^{5}$ ), aldus leeren Visnuiten; gurau tuște çivas tușțo ruște ruștas trilocanah | gurau tuște şivā tuștā ruște rușțā ca sundarī || ato gurur maheçāni samıārāarnavalaṃhane | kartā pātā ca hartā ca gurur mokșapradāyakah (is de guru voldaan, dan is Çiva het, is hij toornig, dan is Çiva vertoornd; is de guru voldaan, dan is Çivā (Devi) het, is hij vertoornd, dan is zij het; vandaar is de Guru bij het overschrijden van de zee van den kringloop der wedergeboorten de Schepper, de Hoeder en de Vernietiger; hij is het, die de verlossing verleent); zoo is de meening van de vereerders van Çiva en Devi $\left.{ }^{6}\right)$; hij is Çiva, ontsproten uit een der gedaanten van Çiva in Kaliyuga ${ }^{\top}$ ); hij is een verschijning, een personificatie van dien god,

1) Vgl. bv. ook Mbh. 13, a. 113, 1.

2) Mahānirvāṇa Tantra, 5, 32, e.a.

3) Kaulāvali-nirnaya (Tantric Texts 14), c. 1.

$\left.{ }^{4}\right)$ Bhāg. Pur., geciteerd bij Wilson, Essays etc., Works I, p. 94, n.

5) Wilson, o.c., p. 165 , n.

6) Zie A. Avalon, Principles of Tantra, II, Introduction by Shrīyukta Baradā Kānta Majumdār, p. LV.

¡) Vgl. Bhandarkar, Vaișnavism, Çaivism, etc. (Grundriss), § 102. 
„,de Hoogste zelf komt als guru en geeft onderricht”, zoo gelooven de Çivaitische $\operatorname{secten}^{1}$ ).

Naast voortdurende pūjā van de Buddha's, onafgebroken yogapraktijk is onvoorwaardelijke gehoorzaamheid aan den guru noodig om het Buddhaschap te bereiken, aldus ook het Mahāyānistische Boeddhisme, en ook hier is de guru gelijk aan Buddha.

Zoo is, in 't kort, de guru in Voor-Indië in jongere tijden in macht en invloed, in beteekenis en vereering toegenomen. Ook onze tekst kent hem groote macht, hooge beteekenis en goddelijkheid toe (als Sadāçiwa). Ook hierin betoont het Agastyaparwa zich in gedachtegang volkomen Voor-Indisch. Vooral wordt echter stilgestaan bij de eigenschappen die een guru dient te bezitten en hij de volgelingen kan doen deelachtig worden. Ook deze onderwerpen komen in VoorIndische geschriften meermalen ter sprake. Voor de ontwikkeling die de denkbeelden op dit punt in lateren tijd hebben doorgemaakt, voor de eischen, die men in theorie aan een guru ging stellen en voor wat zij in de praktijk veelal zijn geworden, verwijs ik naar de hierboven genoemde literatuur ${ }^{2}$ ). In de tantra's is vaak sprake van de eigenschappen en de kenmerken van een guru ${ }^{3}$ ); een onderzoek (parīkșā) naar de kwaliteiten van guru en leerling wordt voorgeschreven.

Enkele opmerkingen zijn nog in de aanteekeningen ondergebracht; van een meer uitvoerige vergelijking is afgezien, daar het onderwerp in grooter verband gezien m.i. wel behandeling in een monographie verdient.

Met dìkșa ${ }^{1}$ ) werd oudtijds aangeduid de wijding voor een godsdienstige plechtigheid, het op-zich-nemen van observanties, wijding; ook de observanties zelf. Zoo vinden we het b.v. bij Manu, 2, 169, gebruikt: de eerste geboorte van 'n Ariër is die uit zijn moeder, de tweede had plaats bij het omdoen van den gordel van muñja-gras (vgl. 2, 42; bij de initiatie), de derde bij de yajñadīkṣā, d.w.z. de initiatie voor het volvoeren van een çrauta-offer. Elders, 6, 29, is het „observantie": etā̧̧ cānyā ç ca seveta dīkșā vipro vane vasan.

Later wordt dỉkșā de initiatie van den leerling door den guru, die noodzakelijk is tot zijn toelating tot de leeringen van de bepaalde

1) Schomerus, Der Çaiva-Siddhānta, eine Mystik Indiens, pp. 290 vlgg.

2) Vgl. vooral Wilkins en Dubois-Beauchamp, t.a.p.

3) Zie bv. Tantrarāja-Tantra (T. T. dl. VIII), hfdst. 1; Kulārṇava-Tantra (T. T. dl. V), hfdst. 12 vlgg.

4) Vgl. B. Lindner, Die Dikṣā oder die Weihe für das Somaopfer, Hab. schr. Leipzig, 1878. 
godsdienstige richting. Bij Visnuitische, Çivaïtische en Çāktistische secten is het de taak van den guru, zijn privilege, om den leerling in te wijden, om door de dikṣā hem de deur tot bovenzinnelijke kennis te openen. Deze wijding brengt den geloovige in contact met de godheid. De leerling is te vergelijken met een patient ${ }^{1}$ ), de guru met den arts, de mantra's met het geneesmiddel. Veelal immers bestaat de wijding in het meedeelen, influisteren van mantra's, mystieke teksten en syllaben. Vaak ook uit meer: Viṣnuitisch is b.v. de inwijding die uit vijf handelingen bestaat ${ }^{2}$ ): tāpa, het branden van de symbolen op het lichaam, puṇ̦ra, het aanbrengen van de secteteekenen op het voorhoofd enz., nāma, het aannemen van een naam, mantra, het ontvangen van de heilige formule, yāga, vereering van de godheid. De formules zijn van dezen aard: Om Bhagavate Vāsudevaya $=$ hulde aan den goddelijken zoon van Vasudeva (= Kṛ̣na); Çrī Rāmāya namah (hulde aan den luisterrijken Rāma), çrī Krṣnah çaranam mama (de hoog-doorluchtige Kṛ̣na is mijn toevlucht) ${ }^{3}$ ).

De Çaiva-Siddhānta leert, dat Çiva verschillende methoden aanwendt om de richtige kennis mee te deelen ${ }^{4}$ ). De guru maakt daarom, naar omstandigheden, gebruik van nayana-dikkṣā (d.w.z. door het oog, de guru ziet den leerling in het oog en verlicht hem zoo); sparça-dīkṣā (door aanraking, ,der Guru berührt 5 wichtige Stellen des Körpers des Schülers und übermittelt ihm so das rechte Verständnis der 5 Buchstaben, der heiligen symbolischen Formel”); vācaka-dỉkṣā (mondelinge onderrichting van mantra, formules en mystische liederen), mānasa-dīkṣā (door middel van hypnose), yogadìkṣā (met behulp van de askese, gèleerd door de wetenschap van den yoga) en andere wijzen.

Een uitvoerige uiteenzetting van de dīkșā, de initiatie hebben we b.v. in het Agni Purāṇa ${ }^{5}$ ). Drie soorten dỉkṣā worden daar onderscheiden; de eerste leidt de kennis van de çāstra's in, de tweede de transcendentale kennis, de derde brengt den geïnitieerde tot kennis van de verlossing.

De thans volgende passage, genealogisch van inhoud, vindt men in de aanteekeningen toegelicht. We dienen hier echter even de aandacht te vestigen op de plaats waar Trnawindu e.a. genoemd

1) A. Avalon, Principles of Tantra, II, Introd. etc., p. XLVIII.

2) Vgl. A. Govindācārya Svāmin, J. R. A. S., 1911, p. 946.

3) Zie bv. Monier Williams, Brāhmanism and Hindūism, p. 117.

4) Schomerus, o.c., pp. 315 vlgg.

5) Adhy. 81 vlgg. 
worden. Deze is stellig van Javaansche origine en in verband :net andere plaatsen in literatuur en op inscripties van interesse.

Paragraaf 23 begint met een overzicht van de plichten van de verschillende standen. Ook dit is een welbekend onderwerp uit smṛti- en purāna-teksten en wat zich daarbij aansluit. Om slechts enkele plaatsen te noemen: de Viṣnu-smṛti geeft, hoofdstuk II, een kort overzicht van de vier standen, hun plichten en wijzen van levensonderhoud $^{1}$ ). Manu spreekt herhaaldelijk over dit onderwerp, b.v. 1, 88 vlgg.; 102 vlgg.; 3, 64 vlgg.; 150 vlgg. (verbodsbepalingen); 10, 1 vlg.; 75 vlg. enz. Plicht van den brahmaan is (Veda-) studie en -onderricht, offeren; van den kșatriya: het volk te beschermen, den Veda te bestudeeren, zich te onthouden van zinnelijke genietingen; van den vaiçya: vee te houden, handel te drijven, land te bebouwen, geld uit te leenen, enz., den Veda te bestudeeren; van den çūdra ${ }^{2}$ ), de drie andere kasten te dienen. Het verwondert ons niet, dat ook de purāṇa's, meer of minder tot in bijzonderheden gaande, de plichten der standen en wat daarbij aansluit behandelen. Zoo vinden we een uiteenzetting in het Viṣnu-Pur. 3, 8, 9 vlgg. ${ }^{3}$ ); het Mārkaṇ̣eya-Pur. spreekt erover in adhyāya 28; het Agni-Pur. in adhyāya 151 . Ook het Mahābhārata heeft, men denke aan het XIIe boek, menige passage aan dit onderwerp gewijd; de Visnuitische Ahirbudhnya-Saṃhitā hoofdstuk $15^{4}$ ). Ook - om deze voor onzen tekst belangrijke werken hier eveneens te noemen — de Brahmāṇ̣̣en Vāyu-Purāna's maken gewag van de plichten der standen; vgl. Bmọ. I, 7, 160 vlgg.; Vā. 8, 168 vlgg.

Daarna gaat het Agastyaparwa over tot een beschouwing omtrent toegestane en verboden huwelijken tusschen de vier standen, en wel in vergelijking met de uitvoerige en ingewikkelde leeringen die we in Sanskrit werken daarover aantreffen, uiterst beknopt. Wat onze tekst op dit punt wil, komt hierop neer: men huwe in z'n eigen stand, echter is het niet ongepast dat een man een vrouw uit één kaste lager neemt, andersom mag niet. Men lette er op, dat Skt. savarna, waarvan de beteekenis is ,vary denzelfden stand” kan aanduiden zoons uit een huwelijk, die den stand huns vaders volgen, ook al is de moeder één stand lager. Op gelijkheid van stand bij een huwelijk werd in het oude Indië reeds in de periode der grhyasūtra's

1) Bij Jolly, S. B. E. VII, p. 12, worden parallel-plaatsen genoemd.

2) Manu, 1, 91; Vișṇu, 2, 8.

3) Vgl. Wilson-Hall, III, pp. 85 vlgg.

4) Schrader, Introd. to the Pãñcarātra, p. 117. 
zeer aangedrongen; de eischen werden echter in den loop der tijden strenger ${ }^{1}$ ). Baudhāyana leert, 1, 8, 16, 6: zoons van vrouwen van gelijken stand of van één stand lager zijn savarna $\left.\bar{a} h^{2}\right)$. Een ander standpunt neemt Viṣnu in $(16,1 ; 2)$ : van ,ebenbürtige” vrouwen krijgt men zoons van den stand van den vader, van vrouwen van lageren stand zoons, die den stand van hun moeder aannemen. Mbh. 13, 47, 17 (= 2515) leert: ,zoons van brahmanen bij vrouwen van de hoogste drie standen zijn brahmanen". Men ziet: verschil van opvatting. Het huwelijk van een vrouw van hoogeren met 'n man van lageren stand wordt echter door de verschillende teksten afgekeurd $^{3}$ ), een strijdvraag was of mannen van hoogere standen met çūdra-vrouwen mochten huwen ${ }^{4}$ ). De purāṇa's maken van deze kwesties eveneens gewag; men vergelijke b.v. Mārk. Pur. 113, 31 vlgg., en Agni Pur., a. 154; in laatstgenoemden tekst mag een brahmaan 4 , een kṣatriya 3 , een vaiçya 2 , een lid van den laagsten stand één vrouw hebben ${ }^{5}$ ). Doch genoeg: de belangstellende lezer moge zelf de materie verder uitputten!

Tenslotte de caturāçrama, de vier levensstadia, eveneens een veelbehandeld onderwerp. In de z.g. wetboeken neemt de behandeling van de plichten en rechten van de vier āçrama's, van de voorschriften betreffende ,scholieren”, huisvaders, woud-hermieten, ,asketenbedelaars" een voorname plaats in; ook elders, b.v. in de purāṇa's vinden we er vaak over gesproken. Men vergelijke b.v. Viṣnu-Purāna 3 , a. 9, in aansluiting bij de beschrijving van de plichten der vier standen ${ }^{6}$ ), zooals vaker - zie b.v. Mārk. Pur. 28, 8 vlgg. - en ook in onzen tekst, en ook in het Bṇ̣̃.- en het Vãyu-Pur., resp. 1, 7, 168 vlgg.; 8, 176 vlgg. Van de verdere meermalen ter sprake gekomen literatuur vermeld ik de Ahirbudhnya-Saṃhitā, die eveneens in vervolg op de bespreking van de vier standen de levensstadia behandelt ,the conception of which is, on the whole, the orthodox one" ${ }^{7}$ ).

Het zich tot hoofdzaken beperkende overzicht van de in ons werk ter sprake komende onderwerpen is hiermede, voor zoover ze zonder

1) Bijzonderheden bv. bij Jolly, Recht und Sitte (Grundriss), p. 61; Meyer,

Das altindische Buch vom Welt- und Staatsleben, pp. 767 vlg.

2) Vgl. Kauțilya 3, 7 (vert. van Meyer p. 260 ond.).

3) Zie bv. Jolly, o.c., p. 62.

4) Zie bv. Jolly, o.c., p. 61 .

5) Agni Pur. 150, 1; vgl. Mbh. 13, 44, 11: br. 3, kṣ. 2, v. 1.

6) Wilson-Hall, III, pp. 92 vlgg.

`) Schrader, o.c., p. 117. 
eenigen twijfel Voor-Indisch van aard en herkomst zijn, teneinde. Thans de vraag: wat is Javaansch? Dat het inheemsche element in elk geval zeer weinig beteekent in vergelijking tot het Voor-Indische staat na bovenstaande uiteenzettingen reeds vast. De episode van Udug basur ( $(8)$ doet Javaansch aan ${ }^{1}$ ); Javaansch zijn de opmerkingen over Tṛnawindu en Mārkaṇdeya in § 22. Voorts is, gelijk reeds opgemerkt ${ }^{2}$ ), wel Javaansche terminologie gebezigd. Hebben we in deze gevallen reden te besluiten tot Indonesische herkomst, zeer twijfelachtig is dit m.i. bij eenige andere passages, waarvoor we geen Voor-Indische parallel konden aanhalen. De beschouwingen in het laatste deel van $\S 7$,' 'n bijzonderheid als de draad in het brahmahatyā-verhaal $(\S 8)$, de leeringen omtrent de karakters van Diti enz. ( $\S 9$ vlgg.) e.a. zijn met meer recht als Voor-Indisch dan als Javaansch van herkomst aan te zien. Het is zeer wel mogelijk, dat er spoedig parallellen gevonden worden: de ontzaglijke omvang en de moeilijke toegankelijkheid van de betreffende literatuur, onthouden mij nu - dunkt me - nog menige vondst. Hoe meer men zoekt, hoe meer zal blijken, dat het Voor-Indische element ook in dit geschrift volkomen domineert.

En door den vorm (vraag-gesprek; çloka's met explicatie) en door den inhoud wekt het Agastyaparwa den stelligen indruk de bewerking te zijn van een Sanskrit origineel.

Er rijst echter thans nog een vraag bij ons, n.1. welke is de godsdienstige richting waaraan de inhoud van het geschrift het naast staat? Ik wil mij bij m'n poging tot beantwoorden van deze vraag zeer beperken, daar ook dit punt beter in grooter verband beschouwd kan worden. Zonder twijfel is het karakter van dezen tekst Çivaitisch. Çiva toch is het, die na den Mahāpralaya, als Sadāçiwa de schepping aan den gang brengt; en ook op verscheidene andere plaatsen wordt de naam van dezen god genoemd. Zoo op p. 356: tilěman bwat hyai Çizwaşrāddha; op p. 359 is, in een ,citaat" sprake van Çiwabhakti; op p. 380 van Çizvamandala ${ }^{3}$ ). Sadāçizia vinden we nog eens, n.1. op p. 392 ; Çizuāditya eenige malen, zie b.v. p. 347, ook p. 378; eveneens Çiwāgni, zie p. 355; p. 356. Çiwaïtisch dus, en van belang voor onze kennis van het Javaansche Çivaisme, van zijn herkomst en van de stroomingen en richtingen, die er in

\footnotetext{
1) Vgl. de aant.

2) Bij de nakșatra's, § 5 .

3) Vgl. O.-J. Bmạ. Pur., p. 94, 26.
} 
vertegenwoordigd zijn geweest. Pigeaud heeft $\mathrm{er}^{1}$ ) reeds op gewezen, dat het Agastyaparwa ook in dit opzicht van gewicht is, en hij had het oog speciaal op tantristische opvattingen. Tantristisch in den engeren zin van Çäktistisch is de tekst zeker niet. Een ,tantra" is het niet. Tantra's plegen te zijn ingekleed in den vorm van een openbaring van den god Çiva in een of andere gestalte aan Devī, zijn Çakti, zijn gemalin; ook zij treedt sprekend op $^{2}$ ); in onzen tekst is dit anders. Devī en haar vereering, zoo op den voorgrond tredend in het Çāktisme, worden hier met geen woord genoemd of aangeduid. $\mathrm{Bij}$ het relaas der schepping zou de gelijkstelling van prakṛti, de oermaterie, met Çakti besproken kunnen zijn; het is niet geschied. Van de pañcatattva, tot den cultus van Devĩ behoorend, madya, māṃsa, matsya, mudrā, maithuna, is nergens sprake; evenmin van yantra's (ritueele diagrammen) ${ }^{3}$ ), mudrā's (ritueele houdingen, handgebaren), nyāsa's (,,the placing of the hands of the worshipper on different parts of his body, imagining at the same time that thereby the corresponding parts of the body of his Ishtadevatā are being there placed" $\left.{ }^{4}\right)$. Mantra's ${ }^{5}$ ) en wat daaraan annex is -, dat wordt niet geleerd. Bij de standen en levensstadia wordt in onzen tekst stilgestaan; ook de tantra's kennen deze, ze voegen echter aan de standen een vijfde, die der sāmānya's, toe en beschouwen slechts huisvaders en asketen als de twee levensstadia. Uitvoerig is het Agastyaparwa bij de behandeling van Dakșa's dochters en hun nageslacht; nergens vinden we eenige zinspeling op de tantristische leer, die personificaties als Puṣti, Tuști, Swāhā, Swadhā, Rati, Prīti, Diti, Aditi, e.a. kalā's, voorstelt als gedeeltelijke incarnaties van het Vrouwelijk Principe, van Prakṛti, of als kalā's van de maan ${ }^{6}$ ).

Ofschoon dus geen tantra en allerminst tantristisch in den zin, die men vroeger wel aan dit woord hechtte, d.w.z. de leeringen en vooral de praktijken van de Vāmacārins volgend, kan men toch wel zeggen, dat er tantristische invloed in valt te onderkennen. Vat men ,tantra's” op in den zin van teksten der Âgama-scholen in het algemeen, in den zin van sectarische geschriften, waarin eensdeels veel

1) Zie boven, p. 356 .

2) Vgl. bv. Woodroffe, Shakti and Shākta ${ }^{3}$, p. 13.

$\left.{ }^{3}\right)$,A yantra is a diagrammatic presentation of Divinity, as mantra is its sound-expression", Woodroffe, o.c., p. 384.

4) O.c., p. 425.

5) Vgl. bv. Woodroffe, o.c., pp. 421 vlgg.

6) Vgl. Tantrarājā Tantra (T. T. 8), hfdst. 7; hfdst. 12; Mahāniruāṇa T. vert. p. 150, e.a.; Wilson, Essays, p. 246. 
oude stof uit purāna's en uit de philosophische systemen, vooral Vedānta, Sāmkhya en Yoga, is opgenomen, anderdeels deze stof wordt verwerkt en uitgebreid met andere leeringen en praktijken, en met een systeem van magische riten, dan vertoonen ook gedeelten van het Agastyaparwa beinvloeding door en samenhoorigheid met dit groote, veelomvattende totaal van geschriften. „Where there is Mantra, Yantra, Nyāsa, Dỉkṣā, Guru and the like, there is Tantra Shāstra” ${ }^{1}$ ). Mogen vele ,onderwerpen” ontbreken, over den geestelijken leeraar en over de initiatie wordt uitvoerig gehandeld. In dien zin hebben zeer vele teksten tantristischen invloed ondergaan. Niet alleen de „na-puranische" Viṣnuitische en Çivaitische literatuur wat na bovenstaande aanduiding van zelf spreekt - ook de purāna's hebben meermalen tantristische passage's; voor 'n werk als het Kālikā Purāna b.v. dient men zich nog veel sterker uit te drukken.

In de dogmatiek Sāmkhya ${ }^{2}$ ) en „Vedānta”, in de ethiek een ontleening aan en een voortzetting van de leeringen, die we ook in Manu en de Bhagadvadgìtā vinden - men vergelijke ook de Boeddhistische preeken -, de plichtenleer in 't algemeen in overeenstemming met de handboeken van moraal; voorts een uitgebouwd Yogasysteem, vermengd met Viṣnuïsme en Çivaïsme, zooals ook de Purānna's dat wel kennen - aan geschriften van dezen inhoud is onze tekst na verwant. Nauwkeurige onderscheidingen tusschen de leeringen der verschillende richtingen, die zeer veel gemeen hebben en elkaar op vele wijzen hebben beinvloed, lijken wegens het geringe beschikbare materiaal nog te moeten worden uitgesteld.

Over de stukjes tekst die in het Sanskrit zijn gesteld, zou, bij aanwezigheid van meer vergelijkingsmateriaal, wellicht veel te zeggen zijn; om niet te zeer in hypothesen te vervallen wil ik er echter kort over zijn. Het werk bevat zeer vele passage's, waarin Sanskrit wordt gebezigd, op \pm 155 plaatsen $\left.{ }^{3}\right)$. Hiervan zijn ruim ${ }^{1 / 3}$ çloka's, $\pm{ }^{1 / 8}$ halve çloka's, ruim ${ }^{1 / 4}$ kwart çloka's, $\pm^{1 / 5}$ bestaat uit $5,7,9,11$ (hiervan 7 à 8), 15 e.a. syllaben. Het laatste aantal, hoewel op zich zelf opvallend, kan ons wellicht tot vermoedens, doch niet tot meer brengen. Deze plaatsen hebben, als nagenoeg steeds het Sanskrit in Oud-Jav. teksten, in de overlevering veel te lijden gehad, doch zijn veelal nog te begrijpen, soms te herstellen. Ze maken op mij, als geheel, den indruk van Voor-Indische makelij te zijn, al kan men

1) Woodroffe, Shakti and Shākta ${ }^{3}$, p. 56.

2) Vgl. echter Garbe, Sāṃkhya-Phil.2, p. 60.

3) Niet medegerekend ư'àca en Drdhasyûrāca (sic). 
een enkele maal met reden twijfelen. Hoewel de tekst zelf vaak aan de Brahmāṇda-Vāyu-versie van de Purāna-stof doet denken en ook de colophon in die richting wijst, zijn de in het Sanskrit gestelde deeltjes van onzen tekst over 't algemeen niet gelijkluidend met vergelijkbare verzen of versdeelen uit genoemde teksten. Wat mij aan overeenstemming en afwijking belangrijk scheen om te doen opmerken heb ik in de aanteekeningen opgenomen. Hier nog dit: in de $\$ \S 6$ vlg. ontmoeten we vele citaten (dit woord mag wel gebezigd worden) die duidelijk parallel zijn, in 'n enkel geval zelfs volkomen overeenstemmen met smrti-passages.

Dit is niet van belang ontbloot. Ook de naam Manu wordt genoemd ${ }^{1}$ ). Wij dienen echter bij dit laatste te berlenken, dat men zich in het Mahābhārata en elders zeer vaak op de autoriteit van Manu beroept om een bepaalde leer als oud en vaststaand voor te stellen, zonder dat het beweerde in ons Mānava-Dharmaçāstra voorkomt, ja soms is het in tegenspraak met wat daar staat ${ }^{2}$ ).

De citaten worden vertaald: vaak wordt de vertaling, als in de Sang Hyang Kamahāyānikan en de Tautri Kāmandaka met kalina-. nya ingeleid; als regel na çloka's, van $\S 12$ tot $\S 17$ echter niet, later meestal weer wel.

Zooals ook in andere teksten is in de in het Sanskrit gestelde passage's de eigenaardigheid op te merken, dat de sandhi-regels niet zijn toegepast. Daar dit ook op inscripties gebeurd is ${ }^{3}$ ), mag :nen aannemen, dat de auteur of bewerker en niet een latere afschrijver deze regels heeft verwaarloosd. Ik heb niettemin gemeend, het Sanskrit op de gebruikelijke wijze te moeten geven.

Het werk wordt in den colophon van eenige handschriften

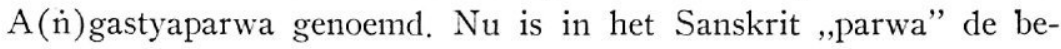
naming van een deel van een uitvoeriger geschrift, en zoo is het ook op Java gebruikt; men vergelijke b.v. Adip. p. 4: ngaran ikang çăstra, Mahābhārata-upākhlyāna ngaran ika; ikang aji pinakapadārtha paprang sang Korawa Pāṇ̣̣awa, ... kunang ika Mahābhārata-tattwa ngaranya, lwir ning para'a: Ādiparwa, Sabhāparwa enz. Vele woorden zijn er voor: verhaal, geschrift, tekst; parwa echter duidt een onderdeel aan. Daarnaast is het woord ook in gebruik gekomen in de meer algemeene beteekenis ,,en toegepast op alle prozawerken,

\footnotetext{
1) Pag. 354 .

2) Vgl. bv. Winternitz, Gesch. der ind. Litt. III, 487; Jahn, Das Sz.urapurāṇam, p. 92, n. 2; ook Meyer, Gesetzbuch und Purāna, p. 9 en n.

3) Vgl. F. D. K. Bosch, T. B. G. 57 , p. $413 ; 64$, p. 227 , n. 1 .
} 
die de bron zijn van dichtstukken" ${ }^{1}$ ); van wanneer af, en of slechts in den lateren vorm prawa, kan ik wegens gebrek aan lexicographisch materiaal niet nagaan.

Voor ons geschrift is het echter van belang de juiste beteekenis van parwa hier te kennen. Handschrift B spreekt kortweg van Agastya. Het bevat echter de ook in $\mathrm{F}$ en $\mathrm{H}$ voorkomende hoogst merkwaardige mededeeling $\left.{ }^{2}\right)$ : iti piturun saì hyai Brahmändamatěkāla-purāṇa nāma ${ }^{3}$ ) sanisipta niyata. Piturun kan beteekenen ,,incarnatie” ${ }^{4}$ ), ,,afstammeling”, ook ,,afkomstig van”.

Turun kan immers, behalve „afdalen”, zijn: „afstamming”, ,,afstammeling”; ,afschrijven”, ,namaken”, ,,vertalen”. In den zin van „,copieeren” zal men het werkwoord hier niet moeten opvatten, immers een „,copie” van het Bmḍ.-Pur. is onze tekst niet. Eerder ,afstammen van"; piturun dus als ,afkomstig van”. Bedoeld zal dus zijn: ,de inhoud ervan gaat terug op...”.

Wat voorts met het woord dat tusschen Brahmāṇ̣a en Purāna staat wordt aangeduid, is mij niet doorzichtig. Bmḍ.-mahāpurāṇa zou zeer begrijpelijk zijn, indien het er stond. Ik gis: verbasterd uit Mahākāla-Pur. ${ }^{5}$ ), doch wil volstrekt niet beweren, dat dat er gestaan moet hebben. Mahākāla is een naam van Çiva, in z'n vernietigend karakter ${ }^{6}$ ); ook op Java is deze naam bekend. Zou het dan een aanduiding zijn van het Çivaïtische karakter van den tekst? Of zou deze titel dan op een compilatie wijzen uit twee geschriften? Een tekst, die den naam Mahākāla draagt is immers bekend, het Mahākāla-Tantra ${ }^{7}$ ). Sanisipta tenslotte leert ons, dat we met een beknopten vorm, met een verkorting te doen hebben.

$\mathrm{Al}$ is deze mededeeling uit den colophon van genoemde manuscripten dus niet geheel duidelijk, we leeren er uit, dat een betrekking tot het Brahmāṇ̣a-Purāna wordt geconstateerd. Maar nu is de vraag: van welk Agastyaparwa, een Javaansch of een Voor-Indisch, tot welk Brahmānḍa-Purāna? Wat het laatste betreft: kunnen we

1) K. B. W. IV, 106.

2) Zie Bijdr. 90, pp. 333 vlg.

3) Zoo, volgens $\mathrm{H}$ :

4) K. B. W. II, 589.

$\left.{ }^{5}\right)$ De $h$ en $t$ worden wel eens verwisseld, vlg. bv. Wulff, Wirāțaparwa, p. 174 ; de toevoeging van de pěpět kan dan op verschillende wịzen verklaard worden. Bij andere woordscheiding m.i. evenmin duidelijk.

$\left.{ }^{6}\right)$ Vgl. bv. Monier-Williams, Brāhmanism and Hindūism" ${ }^{4}$ p. 82.

`) Vgl. Burnouf, Introd. à l'histoire du Bouddhisme indien, (I), Parijs, 1844, p. 539; Farquhar, o.c.; Avalon, T. Gr. Lib.; Winternitz, Gesch. d. ind. I.itt., II, p. 274, - Er kunnen meer teksten van dergelijken naam geweest zijn. 
als het meest waarschijnlijke aannemen, dat er een nauwe band bestaat met den dusgenaamden Oud-Javaanschen tekst? Of gaat ons geschrift terug op een Voor-Indischen tekst, die een Brahmāṇ̣aMa ... kāla-Purāna was?

$\mathrm{Nu}$ bevat de tekst zelve verscheidene indicia, die op een nauwe betrekking tot het Brahmāṇ̣̣a-Purāṇa, d.w.z. de Bmḍ.-Vāyu-versie van de puranische stof ${ }^{1}$ ), wijzen, afgezien nog van de overeenstemming daarmee, tot welke de behandeling van de genealogieën van Dakșa's geslacht ons, vragenderwijs, bracht.

Gaan we een aantal plaatsen na:

1. 347, 9 sai Pawą̧a ... ar pakanak sà Samba, saì Käçyapa; vgl. Bmọ. Pur. 1, 11, 16 Parvaçaḷ ... janayāmāsa vai sutau|Yajurdhāmaṇ ca-Stambhakāçyapam ${ }^{2}$ ); het Vā. Pur., 28, 13 geeft: sutaṇ Kăcyapam; het O.-J. Bmọ. Pur., p. 61, 13: manak ta sira rwa, sain Yajñärdhya mwain sain Kaçyapa ñaran ira. Samb(h)a of Stamb(h)a heb ik elders in dit verband niet aangetroffen.

p. 347, 18 Atinamanā, vgl. Bmḍ. Pur. 1, 11, 27 Atrināmā, O.-J. Bmḍ. Pur., p. 61, 27 san Hatimāna (vgl. het crit. app.), Vā. Pur., 28, 22 Vinīto nāma; zie de aant.

p. 347, 28 saì Satyawatī mwaì saì Swaparā, vgl. Bmụ. Pur. 1, 11, 38 Punyā Satyavatī ca te; O.-J. Bmḍ. Pur. p. 62, 11 saì Satyā mavain saì Suṛti; Vā. Pur. 28, 33 Punyātmasumatì ca te.

p. 349, 4 saì Prabhāta, vgl. Bmọ. Pur. 2, 3, 21 Prabhātaç ca, Vā. Pur. 66, 20 Prabhāsaç ca; zie de aant.

p. 349, 6 sain D. sira makanak sain Dr., saì Hürtahawya, sain Rajah, vgl. Bmḍ. Pur. 2, 3, 22 Dharasya putro Dravino Hutahavyo Rajas tathāa Vā. Pur. (Bibl. Ind.), 2, 5, 21 (=66, 21) ...Hutahavyavahas tath $\bar{a}$, in overeenstemming met vele andere teksten; zie verder de aant.

p. 348,31 sain Dhuni, vgl. Vã. Pur. 66, 31 Dhunis tathāa, Bmḍ. Pur. 2. 3, 30 echter Munis tathā. Niet elders.

p. 349, 14; hier worden zes der twaalf Sādhya's genoemd (vgl. (le aant.); de namen herinneren zeer aan Bmọ. Pur. 2, 3, 17; Vā. Pur. 66, 16. Andere Purāna's maken van de namen geen melding; evenmin het O.-J. Bmḍ. Pur.

p. 362, 22; hier hebben Bmọ. Pur. 2, 3, 67 en Vā. Pur. 66, 66 dezelfde volgorde der namen van de Āditya's als onze tekst; andere teksten niet; zie de aant. Niet in het O.-J. Bmḍ. Pur.

1) Zie mijn Oud-Jav. Bmḍ.-Pur., Inl., p. 15.

2) Vgl. ook de aant. 
p. 366, 23 Krtajit; hier heeft Bmḍ. Pur. 2, 5, 39 Kratujic caiva; Vā. Pur. 67, 80 Kșatrajic caiva. Andere teksten hebben dezen naam niet, evenmin het O.-J. Bmọ. Pur.

p. 370, 33 vlgg.; de passage over Anāyusāa en haar kinderen komt wel in de Bmạ.- en Vã. Pur. (2, 6, 30 en 68, 30) voor (voor bijzonderheden zie de aant.), doch elders, voorzoover mij bekend, niet.

Uit deze plaatsen, die zich nog wel lieten vermeerderen, blijkt duidelijk een zekere verwantschap met de Bmḍ.-Vā.-recensie van de Purāna-stof, en wel nagenoeg zonder dat het Oud-Jav. Bmḍ. Pur. tevens in deze verwantschap betrokken is.

Aan den anderen kant echter zijn er enkele plaatsen, waar het Agastyaparwa tegen de Bmḍ.- en Vā.-Pur. met andere teksten meegaat. Men vergelijke:

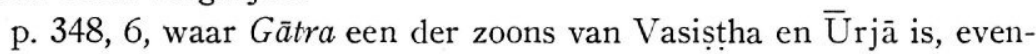
als Agni-Pur. 20, 15, Garuḍa-Pur. 5, 16, Mārk. Pur. 52, 26; vgl. ook Kūrma-Pur. 51, 12; Bmḍ. Pur. heeft echter (1, 11, 41) Gartā (Gartă), terwijl Vā. Pur. 28, 36, een andere lezing geeft.

p. 349, 11 Purojazwa, als Agni Pur. 18, 38, Çiva Pur. Dharmasamhitā 54, 24; Bmḍ. Pur. 2, 3, 26, Vā. Pur. 66, 25 en andere teksten hebben Manojava.

Deze gevallen blijven echter, naar het mij voorkomt, belangrijk in de minderheid.

Een paar plaatsen zijn voorts interessant, omdat daar een overeenkomst met het O.-J. Bmḍ. Pur. is te constateeren.

Op p. 347, 18 leest onze tekst : sain Datoni (zie crit. app.) ; eveneens O.-J. Bmḍ. Pur., p. 61, 29 (vgl. r. 26 en de aant. op p. 244), de Sanskrit teksten hebben allerlei andere lezingen.

Op p. 347, 24 stemt de naam Ambarizuān voor den tweeden zoon van Pulaha weliswaar niet overeen met Hariwān, p. 62, 3, doch men vergelijke p. 114, 4: pinaka-Pulaha saì Ambariwān, apan anak bhagawān Pulaha. Vgl. de aant., p. 245.

Het lijkt mij echter voorshands niet raadzaam veel waarde aan deze gevallen van overeenstemming met het O.-J. Bmọ. Pur. te hechten. Wel meen ik te mogen concludeeren, dat de mededeeling van den colophon over een zekere afhankelijkheid van het Agastyaparwa van de Brahmāṇ̣a-versie van de Purāna-stof ook door deze inwendige gegevens gesteund wordt.

Is het nu mogelijk om eenige niet geheel en al in de lucht hangende gissingen te maken omtrent tijd en plaats van ontstaan van het werk? Voor we trachten hierop te antwoorden, een andere vraag: Vormt 
het geschrift zooals het voor ons ligt een ongeschonden en gaafgebleven eenheid, werk van één auteur of zijn er interpolaties in te onderscheiden? Bij het Oud-Jav. Bmd. Pur. was het betrekkelijk gemakkelijk, de herkomst van iedere passage: Hindoesch of Javaansch, vast te stellen door het ruime vergelijkingsmateriaal, dat de parallelteksten ons boden. Het bleek ons, dat er bijzonder weinig invloed van de Javaansche wereld in te herkennen was, een paar weinig omvangrijke passage's zijn als van Javaanschen oorsprong te beschouwen, waarvan één - die in de inleiding ${ }^{1}$ ) - al zeer goed van den Javaanschen bewerker afkomstig kan zijn. In onzen tekst, waar, zooals we boven zagen, de onmiddellijke herkomst van vele gedeelten, althans voorloopig, niet duidelijk is, moeten we ons met minder positieve conclusies vergenoegen. Dat er een en ander in voorkomt, dat van inheemsche origine is, we zagen het reeds, staat vast. Of dat van den auteur (bewerker) stamt of van een lateren copiiist-omwerker, is een moeilijke vraag.

De tijd, waarin het werk - op Java - ontstaan is, valt slechts binnen zeer ruime grenzen te bepalen. $\mathrm{Er}$ is misschien een terminus ante quem. Het Korawāçrama bevat n.1., gelijk reeds door Pigeaud ${ }^{2}$ ) is opgemerkt, aan het begin ${ }^{3}$ ) een zeer merkwaardige passage; n.1. een opgave van de parwa's van het Mahābhārata. En wel als volgt: Adiprawa, Sabhaprawa, Udehāprawa, Wirațaprawa, Bhīṣmaprawa, Droṇaprawa, Karṇaprawa, Salyaprawa, Swastikāprawa, Histrīprawa, Santiprawa, Hutarekaṇ̣a, Someḍaprawa, Mokșalaprawa, Prașțaikaprawa, Çwarggabheharaprawa, Angastīprawa ${ }^{4}$ ). Men merke op, dat de naam van het Ve Boek, Udyogaparwa, verbasterd in plaats van III, Wanaparwa, is getreden, dat op de $13 \mathrm{e}$ plaats, die van het Anuçāsanaparwa, dat ook in de in het $\overline{\text { Adiparwa }}{ }^{5}$ ) voorkomende opgave van de Mahābhārata-boeken niet vermeld wordt, hier het Uttarakhaṇ̂a optreedt, de bewerking van het laatste boek van het Rāmāyaṇa. Deze invoeging kan berusten op de meening van den auteur, dat ook dit werk een deel van het Mahābhārata uitmaakte ${ }^{6}$ ), een meening, die slechts dan kan post vatten, als juiste kennis van

1) Vg1. schrijver dezes, Het Oud-Jav. Bmḍ.-Pur., p. 18. Van de Andyanmanopassage (p. 19, n. 1) acht ik dit onwaarschijnlijk.

2) T. P., p. 326.

3) Vg1. Cod. Lugd. Or. 4255, p. 2; Juynboll, Cat. II, p. 175.

$\left.{ }^{4}\right)$ Geciteerd volgens Juynboll, t.a.p. Vgl. ook Pigeaud, T. P., p. 330.

5) Zie p. 4 ond. vlgg. Jb. Vgl. ook Kern, V. G. IX, pp. 247 vlgg. en de lijst van Albērūni, India, p. 64 (Sachau, I, p. 133); vgl. ook Kṣemendra.

$\left.{ }^{6}\right)$ Het zou ook copiisten-wijsheid kunnen zijn. 
den inhoud der betreffende geschriften is verloren gegaan. Voorts is het XVe Boek, het Açramawāsikaparwa niet genoemd; de daarop volgende drie zijn inderdaad vermeld; daarna komt tenslotte het „Angastiparwa”. Dient de toevoeging van dezen naam om een bepaald getal vol te maken? Mogelijk, maar ook dit zou er op wijzen, dat hij die de opsomming heeft geschreven geen juist begrip meer had van de genoemde werken. Het Agastyaparwa was voor hem evenals de boeken van het Mahābhārata en het Uttarakhanḍa klassiek, het was een werk uit ouden tijd, waarvan de naam met respect werd genoemd, doch de inhoud nog slechts zeer onvoldoende werd gekend, althans begrepen ${ }^{1}$ ). Daar nu het Korawāçrama een werk is, dat men, afgaande op de beschouwingen van Van der Tuuk ${ }^{2}$ ) en Pigeaud $^{3}$ ), in laten tijd, in de XVe eeuw, misschien nog later, zal moeten dateeren, kunnen we niet alleen met laatstgenoemden geleerde ${ }^{4}$ ) concludeeren, dat het Agastyaparwa, ,altijd aannemende dat 't zelfde werk bedoeld is", ouder is dan het Korawāçrama, maar zelfs, dat het veel ouder is, dat het althans voor dengeen, die de besproken passage schreef, op één lijn gesteld werd met de bewerking van het Mahābhārata en het Uttarakhaṇ̣a.

$\mathrm{Er}$ is nog een geschrift, dat gegevens bevat die van belang zijn om den tijd, waarin ons werk ontstaan moet zijn, nader te bepalen. In de Sang hyang Kamahāyānikan, d.w.z. in Kats' hs. C. komt n.l. de volgende passus voor ${ }^{5}$ ), dien ik overneem om den lezer vergelijking met mijn tekst gemakkelijker te maken:

Sājñā hyaì mami, yukti dahat wuzus rahadyan sainhulun, yatika $\dot{n}$ dewatā sakarĕ̀n munisira kamokșan. aparan ta gawayakěna nin mānușabrata, mwaì mapa lwira nikaì jñāna karĕgĕpanya, yatanyan matěmahana dewatā? kasihana rânak bhatțāra, warahĕn tĕměn-těmĕn.

Uvāca, sumahur bhagazwān Agastya, lïn nira: kiñcit bratī krittiyan tu akrodhan çokavarjitam ${ }^{6}$ ), haywa gön krodha, haywa lobha, hayzo prihatin! nahan tain brata titiga gazwayakĕn in mänușa, yan mahyun

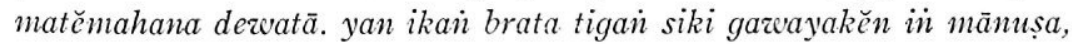
durlabha ika, apan rāgadweșātmaka ikà mānușa, ilik lawan hyun pinakawaknya.

1) De naam, eindigend op -parwa kan tot het misverstand hebben meegewerkt.

2) K. B. W. II, 93.

3) T. P., p. 328 .

4) T. P., p. 326.

5) C. a. 16, Kats, Sang hyang Kamahāyānikan, p. 162.

$\left.{ }^{6}\right)$ Citaat letterlijk. 
Het voorkomen van Agastya's naam merkte Kats ${ }^{1}$ ) reeds op; aan (le passage voegde hij een noot toe ${ }^{2}$ ) : ,dit zeer zuivere en vloeiende Oud-Javaansch is - blijkens de inkleeding van enkele zinnen minstens gedeeltelijk overgenomen uit eene directe vertaling van een Sanskrit-origineel [n.1. het Anggastyaparwa. Juynboll]".

De conclusie ligt voor de hand, dat het Agastyaparwa dus ouder is dan de C-redactie van de Sang hyang Kamāhāyanikan. Er valt evenwel nog een en ander bij op te merken.

Zooals Goris $^{3}$ ) heeft aannemelijk gemaakt, is de C-redactie van genoemd geschrift hoogstwaarschijnlijk een latere, Hindoeistisch georiënteerde bewerking van den aanvankelijk Boeddhistischen tekst, waarvan de A-redactie een vertegenwoordiger is; deze C-redactie zou volgens hem als tijdens of nà Sindok vervaardigd te beschouwen zijn. Waar hij echter in een noot ${ }^{4}$ ) bij zijn opmerking, dat „de vermelding van Agastya als autoriteit (in een „oud" stukje mèt strofen) ons verplaatst in anti-Boeddhistische sfeer" de inscripties van Pereng (A.D. 863) en Dinaya (A.D. 760) vergelijkt en zoodoende behalve aan een niet-Boeddhistische sfeer, hetgeen natuurlijk juist is, ook aan een verband met de Agastya-vereering, zooals die uit gezegde inscripties blijkt, en een mogelijkheid van dateering doet denken, meen $\mathrm{ik}$, dat men deze twee suggesties moet laten voorbijgaan. Zooals ook anderen hebben opgemerkt ${ }^{5}$ ), werpt het Agastyaparwa zeer weinig licht op de Agastya-vereering op Java, al is het zeer goed mogelijk, dat deze vereering de populariteit van het werk ten goede zal zijn gekomen. 'n Enkele maal - zoo de passage waar Tṛnawindu een leerling van Agastya heet ${ }^{6}$ ) - wordt er niettemin op de Agastya-vereering gezinspeeld. Daar de passage's van Javaanschen oorsprong niet van den auteur behoeven te stammen, doch ook van een lateren bewerker afkomstig kunnen zijn, schijnt het mij gevaarlijk toe het geheele werk te dateeren in den tijd, waarin de Agastya-vereering bloeide ${ }^{\top}$ ). Temeer, daar er gegevens schijnen te zijn die er tegen pleiten, de dateering zoo vroeg te stellen.

1) O.c., p. 9 .

2) O.c., p. 162 , n. 1 .

3) Goris, Bijdrage tot de kennis der Oud-Jav. en Balineesche Theologie, Diss. Leiden 1926, pp. 155 vlgg.

$\left.{ }^{4}\right)$ O.c., p. 155 , n. 1 .

5) Pigeaud, T. P., p. 326; Bosch, T. B. G. 67, p. 464.

6) Pag. 394

¡) Vgl. Krom, Hindoe-Jav. Gesch.2, Reg. s.v. Agastya, benevens pp. 183; 193. 
Krom heeft er ${ }^{1}$ ) op gewezen, dat in de vervloekingsformule van inscripties tot en met Sindok sprake is van sandhy $\bar{a}$-dwaya, de twee schemeringen, in de jongere, te beginnen met Airlangga, echter van sandhyā-traya, de drie schemeringen. Daar nu ook onze tekst ${ }^{2}$ ) onder de plichten van een brahmaan rekent: agčlěma ta sirâmūjā matrisandhya ${ }^{3}$ ), zou men hier een gegeven hebben, dat er op wijst, dat hij na Sinḍok ontstaan is, misschien - van Siṇ̣ok tot Airlangga is \pm 75 jaren - zelfs geruimen tijd.

Deze conclusie zou niet in strijd behoeven te zijn met de omstandigheid, dat de C-redactie van de Sang hyang Kamahāyānikan, die den naam van Siṇ̣ok noemt, een passage uit het Agastyaparwa citeert. Ook die tekst kan eenigen, zoo niet geruimen, tijd na de regeering van dien vorst zijn ontstaan.

Bezien we nu het geciteerde fragment eens nader ${ }^{4}$ ). Het correspondeert met p. 387,22 enz. van mijn tekst, doch vertoont hiervan belangrijke afwijkingen; na het begin volgt een andersluidende passage, de tweede helft van den çloka en wat daarop volgt ontbreekt, al wordt alobha uit dien versregel wel in het Javaansche deel gevonden. De laatste zin staat niet in den tekst; het is echter mogelijk, dat deze van den auteur van den Sang hyang Kamahāyānikan-tekst stamt. Evenzoo is het mogelijk, dat deze het citaat heeft geadapteerd, opzettelijk of niet, heeft gewijzigd. Het is echter aan den anderen kant niet uit ie sluiten, dat hij den passus werkelijk zóó in een exemplaar van het Agastyaparwa heeft aangetroffen. Ook de tekst dien wij bezitten is, met name in het laatste gedeelte, zoodanig overgeleverd, dat er m.i. meer voor te zeggen valt, dat de hss.-klassen $\mathrm{x}$ en $\mathrm{y}$ ieder een afzonderlijke ,recensie" vertegenwoordigen, dan dat de onderlinge verschillen door het herhaaldelijke copieeren en de gewoonlijk optredende gevolgen daarvan zouden zijn ontstaan. Dat de Sang hyang Kamahāyānikan een belangrijk afwijkenden tekst van het fragment biedt, kan er dus zeer wel op wijzen, dat reeds in zeer vroegen tijd twee (of meer) recensies van het werk bestonden. Een geschrift als de Sang hyang Kamahāyānikan zelf leert ons al niet anders. Het is zeer goed mogelijk, dat de gedeelten van Javaanschen oorsprong van den vervaardiger van een van deze recensies stammen.

1) Krom, Epigr. aant., T. B. G. 56, p. 482.

2) Op p. $396,15$.

3) Vgl. ook de aant.

4) Een passage met groote gelijkenis met een plaats in de Sairg h. Kam., nl. b 45 is p. 385 , boven. $\mathrm{Zie}$ ook de aant. bij p. 377,10 .

D1. 92. 
Bewerking, excerpeeren van oudere, uitvoeriger teksten, invoeging van gedeelten uit andere teksten, compileeren, ook in Voor-Indië ging het zoo toe: de smṛti- en purāna-literatuur en wat daarbij aansluit is op deze wijze van oudere tijden tot jongere gebracht.

Er zijn voorts nog twee plaatsen in het Agastyaparwa zelf, die van belang kunnen zijn voor de vaststelling van den tijd van ontstaan. In de eerste plaats p. 394, 22 : ndah bhagazūan Byāsa, sira ta magawe ikin Aștādaçaparwa, kacaritan sàn Pāndazwa, Vyāsa, de vervaardiger van deze Aștāaç̧aparwa, de geschiedenis der Pāṇ̣awa's. Stond er bv. ikàn Aștādaçaparwa, dan zou onze tekst hier de Mahābhārataboeken onder den b.v. ook in het $\bar{A}$ diparwa, p. 2 (ngaran ing carita Aștāaçaparwa, gawe bhagawān Byāsa), voorkomenden naam noemen en zou men concludeeren, dat deze ten tijde van de bewerking van onzen tekst in het Oud-Javaansch reeds bestonden. Het woordje ikin verandert evenwel de zaak. Moet men denken aan het bekende ${ }^{1}$ ) gebruik: ikin Yudhișthira $=\mathrm{ik}$, Yudhisțhira, en dus interpreteeren: ,de 18 boeken, de Aștādaçaparwa, waartoe deze tekst behoort”? En zou dan de boven geciteerde ${ }^{2}$ ) passus uit het Korawāçrama door een gegeven uit onzen tekst zelf bevestiging vinden? Zou dan het Agastyaparwa door z'n eigen Oud-Javaanschen bewerker opgevat zijn als een Mahābhārata-boek? Ja, zou het een deel hebben uitgemaakt van de, of een, naar Java gekomen Mahābhārata-recensie? Zeer onwaarschijnlijk, zoolang andere gegevens ontbreken. Behalve de mogelijkheid, dat de plaats geinterpoleerd is, of stamt van een lateren bewerker, een mogelijkheid, waaraan ik geneigd ben de grootste waarschijnlijkheid toe te kennen, te meer, daar de passage in het laatste deel van het werk voorkomt, waarin, zooals we juist zagen, de hss.-klassen $\mathrm{x}$ en $\mathrm{y}$ onderling zoo zeer uiteengaan, dat men aan 't bestaan van twee recensies kan denken ${ }^{3}$ ), - behalve dat is ${ }^{4}$ ) het

1) Bv. K. B. W. I, 135 .

2) Zie pp. 382 vlg.

3) Vergelijk evenwel: Wirāțap. p. 7 ond. Jb.: ....nikeng Wirāțaparwasangkathā, apan prasiddha gumaway ikang Așțādaçaparwa; p. 97, r. 15 katattwan iking Wirățaparwa, tegen p. 97 , r. 10 carita ning Wir., r. 14 kapawitran ing Wir.

4) In een zeer interessante publicatie (T. B. G. 65, pp. 282 vlgg.) deelt Dr. Pigeaud een Nakṣatrarūpa uit een Wariga-geschrift mee, waarvan hij (p. 284) vermoedt, dat het ,naar alle waarschijnlijkheid uit het Anggastyaparwa" is "opgenomen” (op p. 285 spreekt hij reeds van ,het stuk uit het Anggastyaparwa", door den bewerker van de Wariga opgenomen). Het is inderdaad zeer wel mogelijk, dat dit stuk uit het Agastyaparwa afkomstig is en dan uit een tekst, die (zie Pigeaud, p. 286) minder omgewerkt is dan die van mijn uitgave. Indien 
niet uit te sluiten, dat $i k i n$ anders moet worden geinterpreteerd, of ook dat er oorspronkelijk ikain gestaan heeft.

De tweede plaats is p. 367, 9: si Müka naranya..... ikain daitya matěmahan wě̌k si Danalun, sumwab agra nikaì wukir in Indrakīla naranya, kan parwa carita ikà pinatyan de saì Arjuna sĕdaì Bhațtāra Kirātarüpa. Hier worden dus zeer duidelijk bedoeld de gebeurtenissen uit het Kairātaparva van het IIIe Mahābhārata-boek, in het Javaansch wèl bekend uit de Arjunawiwāha. Verwacht men nu niet, wanneer 't (O.-Jav.) Agastyaparwa geschreven is nà 't jaar van vervaardiging van de zoo geliefde Arjunawiwāha (Airlangga, vóór 1035), in plaats van kain parwa carita een andere uitdrukking? Wil juist de omstandigheid, dat er staat parze'a, dat, zooals we boven ${ }^{1}$ ) gezien hebben, hetzij ,deel van een uitvoeriger werk”, hetzij „prozawerk, dat de bron is van een gedicht" beteekent, er niet op wijzen, dat het fraaie kunstgedicht, de Arjunawiwāha, den auteur nog niet bekend was, dat het Agastyaparwa dus ouder is? Dit zou een overhaaste gevolgtrekking zijn. Ten eerste, omdat de auteur, zelfs al zou de Wiwāha hem zeer goed bekend zijn, toch de er aan voorafgaande prozatekst heeft kunnen citeeren. Ten tweede, omdat hij de gebeurtenissen uit het Kairātaparva anders citeert, dan ze in de Wiwāha beschreven staan. Immers in het gedicht komt de Javaansche benaming voor het everzwijn, si Damaluṇ ${ }^{2}$ ), niet voor. Het waarschijnlijkste is dus, dat onze tekst de Kairātaparva-gebeurtenissen in 'n andere recensie volgt dan we ze kennen uit de Wiwāha. Een parallel vinden we in zijn vermelding van de Lawaṇaepisode uit het „Rāmāyaṇa-carita” ${ }^{3}$ ).

dit zoo is, hebben we niet slechts het genoemde vrij ingrijpende verschil tusschen $\mathrm{x}$ en $\mathrm{y}$ te constateeren, doch bovendien het eenmaal aanwezig zijn van een van $x$ en $y$ afwijkenden en om interne redenen - voorzoover we uit de kleine nakṣatra-passage kunnen zien - meer oorspronkelijken Agastyaparwa-tekst. We mochten wenschen deze in z'n geheel terug te vinden. Even goed echter bestaat - naar ik althans nu zie - de mogelijkheid, dat de Nakșatrarūpa niet uit het Agastyaparwa, doch uit een soortgelijken tekst stamt. Derhalve heb ik er mij, in dit dubieuze geval, van onthouden het op zich zelf hoogst merkwaardige stuk nader in deze beschouwingen te betrekken.

1) Zie p. 378 .

2) Zie glossarium, reg. v. eigennamen en aanteekeningen. Vergelijk bovendien : H. H. Juynboll, Die Hölle u. s. w., Baessler-Archiv IV, 1913, p. 82. Men kan parwa carita (cf. O.-J. Rām. 8, 149: kathā carita), behalve als ,het parwa en het verhaal, de geschiedenis, de vertelling" misschien ook opvatten als parwacarita, ,'t parwa-verhaal".

3) Zie p. 373, 22 en aant. Vergelijk ook de samenvattende opmerkingen bij Krom, Hindoe-Javaansche Geschiedenis ${ }^{2}$, pp. 174 vlg. 
Deze twee passage's uit onzen tekst leveren dus vooralsnog geen zekere gegevens voor de vaststelling van den tijd van ontstaan. Ze zijn evenwel in gedachte te houden. We willen geen in de lucht hangende hypothesen, geen uitspinnen van theoretisch-denkbare mogelijkheden, doch dienen te wachten tot den tijd, waarin betrouwbare gegevens zoo voldoende aanwezig zullen zijn, dat we binnen de grenzen van ons kunnen tot een conclusie mogen komen.

Resumeerende meen ik, voorloopig, voor het meest waarschijnlijke te moeten houden, dat het Agastyaparwa zal zijn ontstaan in een tijd, die niet ver ligt van den tijd van de bewerking van de boeken van het Mahābhārata. Voorts acht ik de kans, dat het werk nagenoeg in z'n geheel - afgezien van de ,Javaansche” passage's - uit een Sanskrit geschrift bewerkt is, groot. Neemt men dit niet aan, dan is onder meer de afwijking in allerlei details van het Oud-Jav. Brahmāṇda-Purāna opvallend ${ }^{1}$ ) en zal men ook het bestaan op Java van de ,theologische" gedeelten hebben aan te toonen in uit het Sanskrit bewerkte teksten, van waar uit de auteur van onzen tekst ze heeft kunnen kennen. Ik geef echter toe, dat dit geen afdoend argument is: deze werken kunnen zijn verloren gegaan.

1) Vgl. hierboven, vrl. p. 359. 